\title{
3 The wider semantic field of 'science' in the classical languages
}

\$1 The insight that words are not atom-like entities that bear meaning by and in themselves without relation to others, but that they ought rather to be likened to Leibnizian monads that mirror all other monads in a large network, was first developed by Jost Trier. ${ }^{1}$ The German scholars Jost Trier and Walter Porzig address semantic fields as Sinnbezirke, Wortfelder, or Bedeutungsfelder and point out that semantics must take into account the structure of language. Indeed, there is usually semantic anisomorphism between languages, as few (if any) words cover exactly the same semantic ground in any two languages. A prime example of this are colour words, which cover a physically 'objective' radiation spectrum very differently in different languages. Such (admittedly not always so easily definable) 'denotational fields' are divided differently in different languages. There is no need to enter here into the (difficult) theoretical discussions about how exactly such fields should be conceived of and how they can be precisely defined; instead, semantic fields will be employed in this chapter simply to study terms for activities similar to those we call scientific today, and their names in Greek and Latin. The present chapter will thus take a look at the most important related terms in the ancient languages; chapter 5 will then seek to visualise a web of meaning between them.

\$2 We have seen that awareness of a concept 'science' was still in a nascent phase in the time of Plato and Aristotle - indeed, it was strongly shaped by the latter and such a concept was not yet clearly fixed to any single Greek word. Taking a look at the usage of other terms for the scientific acquisition of knowledge at that time will thus be rewarding. In many cases, this vocabulary was later taken over by Latin one-to-one. Latin used a kind of interpretatio romana not only for Greek divinities $^{2}$ but also for philosophical and scientific terminology. Even in the first century BC or earlier, Classical Antiquity often fixed the translations of these

1 The theory of such semantic fields goes back to Trier (1931). He points out: 'Die Geltung eines Wortes wird erst erkannt, wenn man sie gegen die Geltung der benachbarten und opponierenden Worte abgrenzt. Nur als Teil des Ganzen hat es Sinn: denn nur im Feld gibt es Bedeutung' ('The purport of a word is only recognised when it is distinguished from the purport of neighbouring and opposing words. Only as part of the whole does it make sense: for only in the field does meaning exist'; 6). Today, such approaches have led to very promising digital approaches such as WordNet (https://wordnet.princeton.edu), which are, however, still very much in their infancy. 2 This sometimes led to questionable results, such as Diana = Artemis.

Ә Open Access. @ 2021 Philipp Roelli, published by De Gruyter. @BY BY This work is licensed under the Creative Commons Attribution 4.0 International License.

https://doi.org/10.1515/9783110745832-004 
Greek words to exactly one Latin equivalent in each case. ${ }^{3}$ The corresponding Greek and Latin words will therefore be studied together in this chapter. Several circles of key terms around the concept 'science' may be distinguished. The broader ones are only hinted at; this chapter focuses on near-synonyms of غ̇лt$\sigma \tau \dot{\eta} \mu \eta /$ scientia. Antonymic terms will not be considered, except in passing if they help determine the exact meaning of the positive terms. The approach here will try to remain descriptive and, as far as possible, to understand the web of meaning among the words in question independently of their diachronic development; the latter is of course undeniable and will be treated in part 2 of the book. The focus here will be on the meanings these key terms acquire in classical times: for Greek its classical age around the fourth century BC, and for Latin the two centuries around the birth of Christ. Some remarks on later use, especially at the late mediaeval universities, are interspersed. ${ }^{4}$

The history of philosophical and scientific Latin (and Greek) terminology has been studied occasionally since the Renaissance, especially by some of the reference-work authors encountered above: Rudolph Goclenius' Lexicon philosophicum (1613), Étienne Chauvin's Lexicon rationale (1692), or Plexiacus' Lexicon philosophicum (1716). ${ }^{5}$ Beyond the linguistic medium of Latin, Eucken's fundamental, although in its conclusions sometimes rather sweeping, Geschichte der philosophischen Terminologie (1879) and Snell's (1924) dissertation on the Greek terminology of knowledge provide information for the present chapter.

We begin by returning to the verbs that denote knowledge in the classical ton-

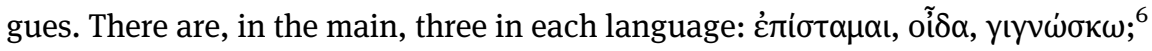
scio, sapio, ( $\operatorname{cog}$ )nosco - they tend to correspond to one another in that order. The words had in classical times largely become synonyms, although in some authors

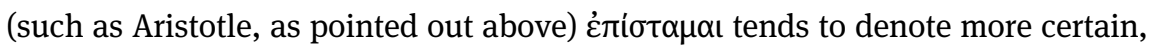
'scientific' kinds of knowing. The character of the perfective oí $\delta \alpha$ is a comprehensive 'having seen and grasped something'. The missing present and aorist forms

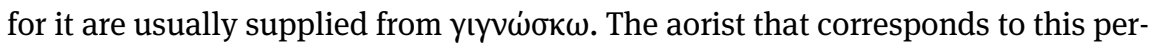

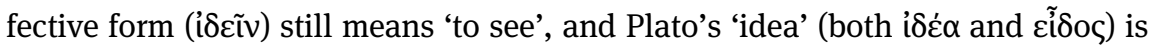
derived from this same root. The Latin verb scio may be related to scindo ('cleave')

3 The later use of some of these words among Latin translators can be seen in Roelli (2014a: 950953) and in more detail online at http://mlat.uzh.ch/MLS/texts/technica.html.

4 This setting sees important change and is well documented by Teeuwen's (2003) encyclopaedic work.

5 On some of these lexicons, see Canone (1997).

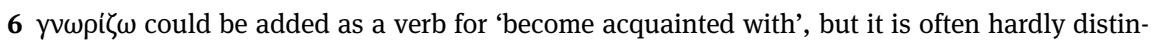
guishable from mere 'to know'. Metaphysica A1, 981a, where Aristotle uses it as a synonym for oî $\delta \alpha$, is quoted below. 
and thus etymologically mean something like 'to distinguish', ${ }^{7}$ while sapio primarily meant 'to taste'. Cognosco stems from the same Indo-European root for 'to

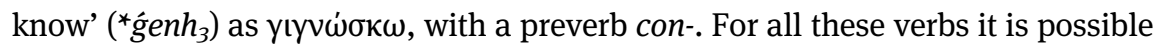

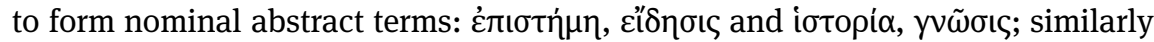
in Latin: scientia, sapientia, cognitio and (rare) gnaritas. ${ }^{8}$ The nuances, however,

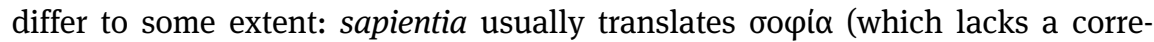
sponding primary verb in Greek), while yvẽoıs has a tendency toward mystical knowledge, which cognitio lacks. This latter word stays close to the general meaning of scientia, mainly adding to it an inchoative character, thus tending toward 'getting to know, realising, becoming acquainted, cognisance'.

It has been shown that a concept of 'science' is only emerging in Greek Antiquity, but even for Hellenistic times D’Ooge can still claim (1926: 16) that $\tau \dot{\varepsilon} \chi v \eta$, $\pi \rho \alpha y \mu \alpha \tau \varepsilon i \alpha,{ }^{9} \mu \varepsilon \dot{\theta} \theta \delta \delta$, and $\varepsilon \pi ı \tau \eta \dot{\mu} \mu$ 'were used in about the same sense, as "a system or body of rules and principles" of any art'. Among the Latin terms - especially scientia, ars, disciplina, doctrina - a similar situation can be observed (e.g. Teeuwen 2003: 358-360). At a closer look, however, differences do appear, although the usage can vary between authors, schools, and periods; for instance,

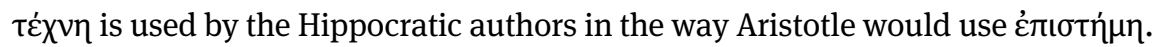
Some such near-synonyms will be discussed in more detail in what follows. The closest semantic field consists of terms that can denote scientific activity or the ac-

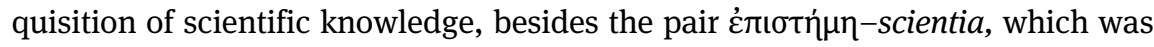
considered above.

\section{$\mu \alpha \dot{\theta} \theta \boldsymbol{\mu} \alpha, \mu \alpha \dot{\theta} \theta \eta \sigma \mathrm{s}$ - disciplina}

\$3 The rather broad Latin term disciplina ${ }^{10}$ ('branch of learning; instruction; (military) discipline') often corresponds to what we would call 'science' in Latin Antiquity. Etymologically, it corresponds best to $\mu \alpha \dot{\theta} \theta \eta \alpha \alpha$ (often plural), as it was felt to belong to disco (cf. the Isidore quotation at the end of this section). Má $\theta \eta \mu \alpha$ is an-

7 See de Vaan (s.v. scio), and LIV under ${ }^{*} s e k H$ : ‘abtrennen: 1. schneiden, 2. unterscheiden' ('sever: (i) cut, (ii) discern').

8 Among antique authors gnaritas is used only a few times, by Sallust and Ammianus Marcellinus, apparently always in conjunction with locorum.

9 This word is sometimes used to denote a philosophical system or a 'systematic or scientific historical treatise', but more often the word means in general any 'prosecution of business, diligent study' (LSJ, s.v.), and it is not considered further here.

10 Probably from ${ }^{*}$ dis-capio ('take up mentally'), leading to discipulus, thence disciplina, with probable semantic influence from disco (see Walde \& Hofmann, s.v. disco). 
other word apparently not found in Ionic but frequent in Attic, ${ }^{11}$ whereas the more active, subjective form of acquiring 'learning' is called $\mu \alpha \dot{\theta} \theta \eta \sigma \varsigma$, , also in Ionic authors. As the object of learning, $\mu \alpha \dot{\theta} \theta \eta \mu \alpha$ can correspond to Latin disciplina or doctrina (on which see §8). However, in Latin disciplina often designates the various fields of scientiae and artes, while $\mu \alpha \dot{\theta} \theta \eta \mu \alpha$ develops from 'learning' in general more and more toward mathematical learning. The Pythagorean Archytas (d. ca. $350 \mathrm{BC}$ ) already used it to denote something like 'exact, mathematical science' (D14 LM = B1 DK):

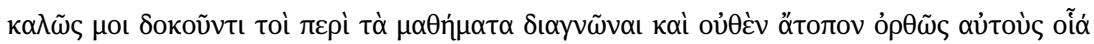

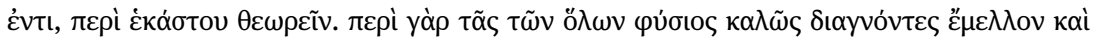

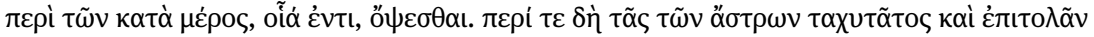

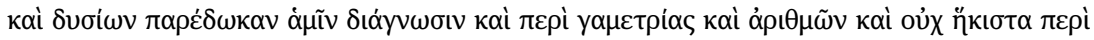

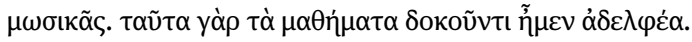

'It seems to me that those studying the $\mu \alpha \theta \dot{n} \mu \alpha \tau \alpha$ discern well, and it is by no means strange that they are able to think correctly about each thing. For as they discerned the nature of everything well, they will also understand how its parts are. They handed down to us clear insight about the speed of the heavenly bodies and their rising and setting, equally about geometry, numbers, and not least about music. For these $\mu \alpha \theta$ ń $\mu \alpha \tau \alpha$ seem to be siblings of one another.'

So the mathematical sciences that will become the quadrivium (geometry, arithmetic, astronomy, music) are here already seen in close kinship and called $\tau \dot{\alpha}$ $\mu \alpha \theta \eta \dot{\mu} \mu \alpha \tau \alpha$. In Aristotle $\mu \alpha \theta \eta \dot{\eta} \mu \alpha \tau \alpha$ is exclusively used for mathematical learning,

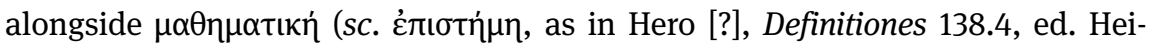
berg, p. 162). This 'mathematics' usually also contains the other mathematical disciplines such as optics, acoustics, statics, and astronomy (and with it astrology). Aulus Gellius writes that (Noctes atticae I.9.6, ed. Marache, vol. 1, p. 39)

geometriam, gnomonicam, musicam ceterasque item disciplinas altiores $\mu \alpha \theta \dot{\eta} \mu \alpha \tau \alpha$ veteres Graeci appellabant.

'the older Greeks called geometry, the art of making sundials, music, and the other similar higher disciplines $\mu \alpha \theta \dot{n} \mu \alpha \tau \alpha$ '.

The Greek word is also used in Latin (incidentally hinting that disciplina was not felt to be close enough to convey the meaning of $\mu \alpha \theta \dot{\eta} \mu \alpha \tau \alpha)$ for 'mathematics'. An exception is found again in Aulus Gellius (XIV.3.5-6, vol. 3, p. 134), who indeed translated $\mu \alpha \theta \dot{n} \mu \alpha \tau \alpha$ with mere disciplinae.

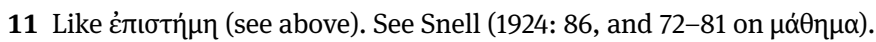


From Roman times onward, mathematica can as totum pro parte also denote 'astrology', for example in Suetonius. ${ }^{12}$ In legal terminology, this meaning can still be found in the Codex Iustinianus in a decree of the year 294: ${ }^{13}$

Artem geometriae discere atque exerceri publice intersit. Ars autem mathematica damnabilis interdicta est.

'To teach or to practise the art of geometria is to be of public interest. The damnable "mathematical” art, however, is forbidden.'

Later, a poem by Bernardus Silvestris (fl. 1147) asserting freedom from astrological fatalism is called Mathematicus. ${ }^{14}$ Hugh of St Victor even uses mathematica in the sense of 'magic arts' in general (besides using the same word for the quadrivium in its entirety): ${ }^{15}$

Mathematica dividitur in tres species: in aruspicinam, in augurium, in horoscopicam.

'Mathematica is divided into three species: inspection of victims, augury, horoscope casting.'

The more usual, narrow, use of the term as we find it today in English is defined by Johann Christoph Heilbronner (1706-1747) in his Historia matheseos (p. 1) thus: ${ }^{16}$

Mathesis est scientia, omnia, quae numero gaudentur, dimetiendi.

'Mathesis is the science of measuring everything that admits of number.'

In this narrow sense of 'mathematics', we see that the Greek term has not found a translation in Latin or the modern vernaculars but is used tel quel, both as mathematica and mathesis. Most modern European vernaculars use the Greek word when they speak of 'mathematics'. Exceptions are Dutch wiskunde (literally 'study of knowing') and Icelandic stærðfræði (literally 'study of quantity'), which use typically Germanic compounds.

12 Tiberius 69, Nero 40, ed. Ailloud, vol. 2, pp. 54, 187.

13 C 9.18.2, ed. Krüger \& Mommsen: De maleficiis et mathematicis et ceteris similibus ('On sorcery and "mathematics" and other similar arts'). The background is that the emperors were understandably particularly unhappy with astrologers predicting their death date.

14 It is based on a Pseudo-Quintilian declamation from which Bernardus will have taken this usage. Much later, Gian Vittorio Rossi, Eudemia VIII.20, ed. Nelson, p. 398, still uses mathematicus in this sense.

15 Didascalicon 6, appendix C, ed. Offergeld, pp. 410-412. The authenticity of this appendix is unclear (p. 403).

16 Heilbronner Historia matheseos, p. 13, also points out the various uses mentioned above. 
As has already been mentioned, the word disciplina has a broad spectrum of meaning; it can also translate $\pi \alpha 1 \delta \varepsilon i \alpha^{17}$ or be synonymous with eruditio. ${ }^{18}$ The loanword 'discipline' is still used today in rather different meanings: from $\pi \alpha \mathrm{t} \delta \varepsilon \dot{\alpha} \alpha$ to 'branch of a science'. In Antiquity disciplina often means '(one specific branch of) science', and indeed not only or not even usually only the mathematical sciences. ${ }^{19}$ In fact, the word can translate غ̇лıбт́ $\mu \eta$, especially in Platonic contexts. ${ }^{20}$ Calcidius ${ }^{21}$ translates غ́лı his translation of the Timaeus; on the other hand, he also once translates $\mu \alpha \dot{\theta} \theta \eta \alpha$ as scientia. As Lewis \& Short (s.v.) put it, disciplina can be 'all that is taught in the way of instruction, whether with reference to single circumstances of life, or to science, art, morals, politics, etc.'. Teachability and a systematic nature are thus central for disciplina; so, Cicero's contemporary Aulus Caecina Severus spoke in his (lost) work on divination of the etrusca disciplina. His aim will have been to reconcile Etruscan lore with the Stoic 'scientific' worldview that was current at the time. ${ }^{22}$ Vitruvius (I.1.12) speaks of the unity of all disciplinae (quoted in chap. 4 $\S 5$ below).

In Latin Antiquity, philosophia itself is also a disciplina, indeed the 'royal' one (disciplina regalis) for Apuleius (Florida 7, ed. Vallette, p. 134); or, conversely, all branches of science and learning can be disciplinae of philosophia. ${ }^{23}$ Indeed, Apuleius seems to use ars, disciplina, and doctrina as synonyms (Bovey 2003: 73), as does Augustine (with the addition of scientia; 76). Bovey comes to the conclusion that these Latin words started out more or less synonymous and it was only in Late Antiquity that some writers tried to distinguish nuances in them. Given their mostly obvious link to existing Greek terminology, this looks like an oversimplification, at least where authors aware of these Greek nuances are concerned. Nonetheless, it seems that in Latin Antiquity scientia and disciplina can both be used to

17 e.g. Augustine, Enarrationes in Psalmos Ps 118, sermo 17.2, ed. Dekkers \& Fraipont, vol. 3,

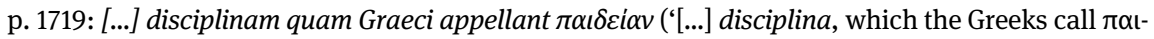
$\left.\delta \varepsilon i \alpha^{\prime}\right)$.

18 e.g. Rufinus, Basilii homilia 5.5, ed. Lo Cicero, p. 88: Disciplina vel eruditio est institutio quaedam cum labore adhibita animae ('Disciplina, or eruditio, is a certain institution applying labour to the soul').

19 On this term's broad spectrum of meanings, see Mauch (1941) and also Hadot (1984: 90 and passim).

20 e.g. Apuleius, De Platone et eius dogmate II.9, ed. Beaujeu, p. 86, or Ps-Augustine, Categoriae 11.95, ed. in Aristoteles Latinus 1.1-5, p. 154.

21 According to the word index of Waszink's edition, where loci can be found.

22 Some fragments are preserved by Seneca in his Naturales quaestiones II.31-49, ed. Hine, pp. 88-97 (on lightning).

23 e.g. Cicero, Lucullus 3.7, ed. Plasberg, p. 29. 
denote 'science', often being more or less synonymous, with the difference that scientia also has the wider meaning of 'knowledge' (as seen in chap. 2 \$5 above) and disciplina a connotation of various branches of learning. Isidore (Etymologiae I.1.1-3, ed. Lindsay) puts it thus: ${ }^{24}$

De disciplina et arte. Disciplina a discendo nomen accepit: unde et scientia dici potest. Nam scire dictum a discere, quia nemo nostrum scit, nisi qui discit. Aliter dicta disciplina, quia discitur plena. Ars vero dicta est, quod artis praeceptis regulisque consistat. Alii dicunt a Graecis hoc tractum esse vocabulum ánò $\tau \tilde{\eta} \varsigma \dot{\alpha} \rho \varepsilon \tau \tilde{\eta} \varsigma$, id est a virtute, quam scientiam vocaverunt. Inter artem et disciplinam Plato et Aristoteles hanc differentiam esse voluerunt, dicentes artem esse in his quae se et aliter habere possunt; disciplina vero est, quae de his agit quae aliter evenire non possunt. Nam quando veris disputationibus aliquid disseritur, disciplina erit: quando aliquid verisimile atque opinabile tractatur, nomen artis habebit.

'On disciplina and ars. Disciplina comes from disco [to learn], whence it can also be called certain knowledge [scientia], as "to know" [scio] comes from "to learn" [disco], because none of us knows unless he learns [disco]. In another manner, disciplina is said because it is learned [disco] fully [plenus]. In fact, ars is called so because it consists of strict [artus] pre-

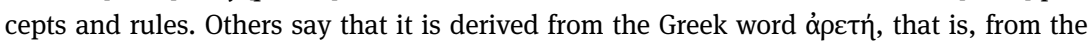
"virtue" called certain knowledge [scientia]. Between ars and disciplina Plato and Aristotle would posit the distinction that ars is about things that can also be different, but disciplina is about things that cannot turn out differently. So, when something is studied using true arguments it will be a disciplina, when it is treated in a manner [only] resembling truth and open to opinion, it will have the name ars.'

Thus, Isidore (or his source) is clearly taking disciplina to be the Roman translation of $\dot{\varepsilon} \pi \iota \sigma \eta \dot{\mu} \mu$ in this quotation and scientia as a synonym for it. This approach is common; the medical writer Ps-Soranus (Late Antiquity), for instance, writes similarly (Quaestiones medicinales, ed. Fischer, p. 33):

Quid est disciplina? disciplina est scientia immutabilis cum ratione.

'What is disciplina? Disciplina is immutable knowledge based on reason.'

As mentioned above, only in the twelfth century is scientia finally preferred (over disciplina) as the standard Latin term for 'science'. This will be pursued below (chap. 10 §6).

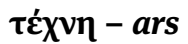

\$4 The pair of terms $\tau \dot{\chi} \chi \nu \eta$ and ars correspond much more closely to one another than $\mu \alpha \dot{\theta} \theta \eta \mu \alpha$ and disciplina. According to $T L L$ (s.v.), ars was a

24 See the discussion of this passage in Hadot (1984: 207-208). 
vox rara apud priscos, dein per totam viguit latinitatem. notionem primitivam in prosam induxere Sall. Liv. Tac. potissimum.

'rare word among the old writers; thereafter it becomes common throughout all of Latinity. Its basic notion was mostly introduced to prose writing by Sallust, Livy, Tacitus.'

Among the old writers who do use the word quite often is Plautus, where it tends to mean a 'gute od. schlechte Eigenschaft, Gewohnheit, Handlungsweise, Tugend od. Untugend, Laster' ('good or bad quality, habit, conduct, virtue or lack thereof, vice'; Georges, s.v. ars), ${ }^{25}$ a usage that led later authors to an etymologia from

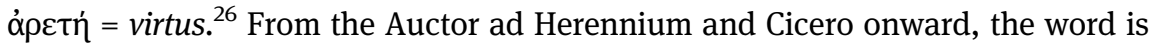
usually very similar in meaning to té $\chi v \eta$. Our 'art' is, of course, derived from ars, but both the Greek and the Latin words had no connotation of virtuosity, unlike

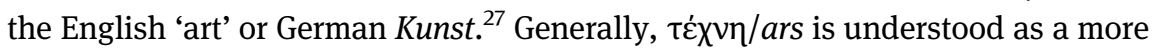

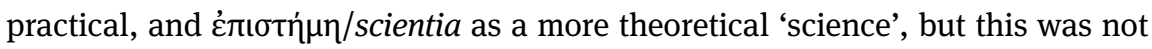

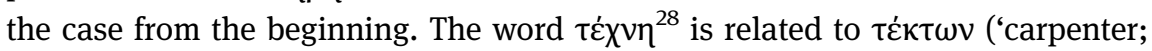
craftsman') in general, but also tik $\tau \omega$ ('bring into the world, engender', esp. children) and to Sanskrit vtakṣ ('fashion, form, invent'); ${ }^{29}$ these words have a definite practical connotation in common. The basic meaning of $\tau \dot{\varepsilon} \chi \vee \eta$ is 'art, skill, cunning of hand.$^{30}$ Nonetheless, the Hippocratic writers use $\tau \dot{x} \chi v \eta$ for their medical 'art', although they certainly mean to emphasise its factual and often theoretical, thus scientific character. Snell (1924: 85) relates this to their Ionic dialect, which

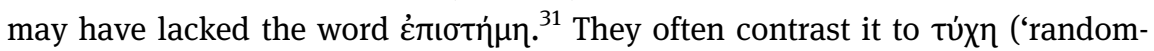
ness'), with which it alliterates conveniently. The understanding of $\tau \dot{\varepsilon} \chi v \eta$ in the Hippocratic treatise De arte is apparent in the very first sentence (1.1, ed. Jouanna et al., p. 224):

25 But the later meaning close to disciplina can already be found too; e.g. Miles gloriosus 2.2, line 32, ed. Lindsay, vol. 2. The ars parasitica in Captivi 3.1, line 9, vol. 1, illustrates the transition between the two meanings well; see Lodge (s.v. ars).

26 e.g. Isidore, just quoted.

27 This difference is explored by Heidegger's (1977) study of the Kunstwerk.

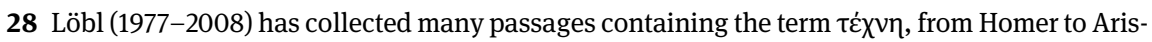
totle.

29 Thus Mayrhofer (1956-1980: 1:468). The $\chi$ is regular: $\tau \dot{\chi} \chi v \eta<{ }^{*} t e k s-n \bar{a}$.

30 Heidegger (1979: 203) translates as 'Sichauskennen in etwas'.

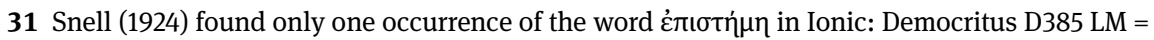

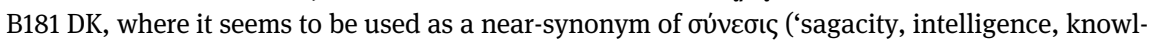
edge, insight'), another word that is occasionally used to denote branches of science, once in Aristotle, Politica IX.8, 1342b8, speaking about the 'science' of music. 


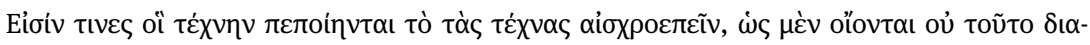

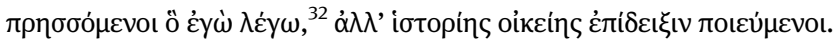

'There are some who have made it an art to vilify the arts, but they do not intend to accom-

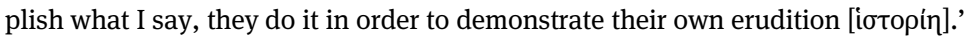

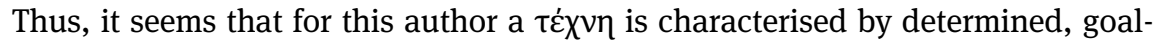
directed, methodical action, the aim in this case being to vilify the arts, especially

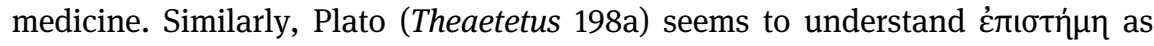

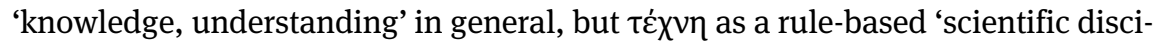
pline':

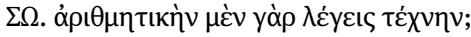

$\Theta E A I$. Naí.

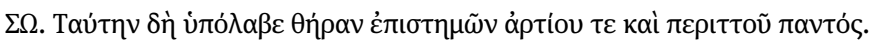
'SOCRATES: Do you call arithmetic an art?

THEAETETUS: Yes.

SOCRATES: Understand it fully as chasing after (scientific) knowledge of even and odd [numbers].'

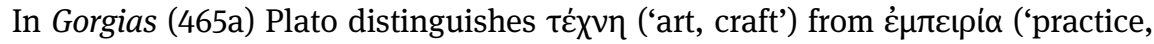

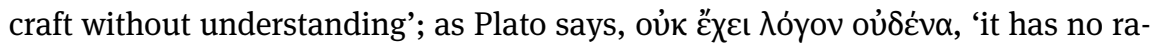
tional understanding') - a distinction that often recurs in later writers. Already in Plato, $\tau \varepsilon ́ \chi v \eta$ can also denote a technical treatise (e.g. Phaedrus 271c). For Aristo-

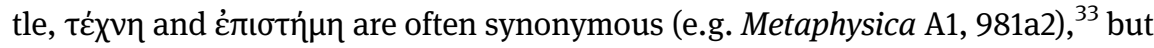
in some passages he stresses that the former is more practical, as in Metaphysica

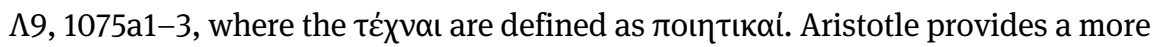

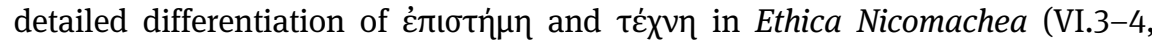
1139b15-1140a23):

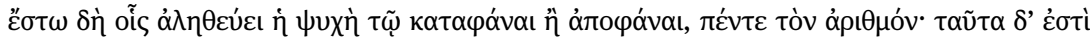

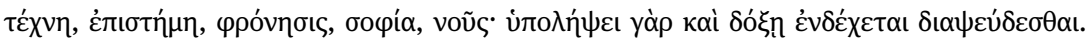

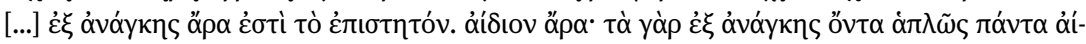

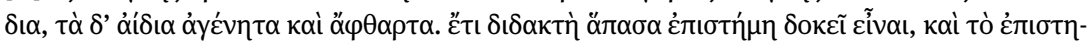

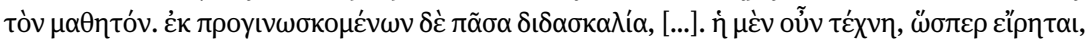

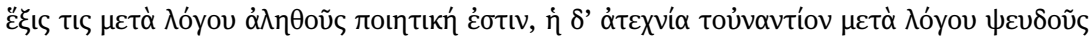

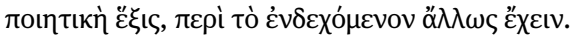

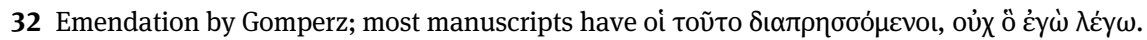

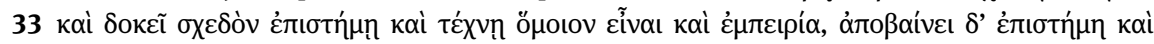

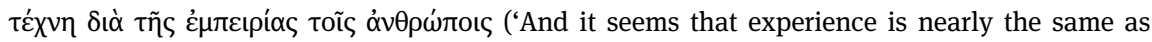
science or art, but science and art reach man through experience'). 


\begin{abstract}
'There will be five means by which the soul can possess truth by affirming or denying; they are practical art, scientific knowledge, practical wisdom, philosophical wisdom, intuitive intellect; for suspicion and opinion can also be wrong. [...] Therefore, the scientifically knowable is of necessity. Thus also eternal; for all things that are of necessity in an unqualified way are eternal. Eternal things are uncreated and imperishable. Again, every science is thought to be teachable, and the scientifically knowable learnable. All teaching comes from what is previously known, [...] art, therefore, as has been said, is a productive state with true reasoning, lack of art contrariwise is a productive state with false reasoning about matters that can also be different.'
\end{abstract}

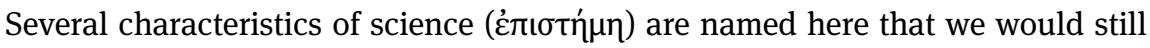
agree with today: it is teachable, it seeks certainty, and it takes what is already known as its point of departure. On the other hand, the objects of $\tau \dot{\varepsilon} \chi v \eta$ are things to be made or constructed; $\tau \dot{\varepsilon} \chi \nu \eta$ is the means to rationally make or produce them, so approaching our 'technology'. Thus, with Aristotle the distinction between scientia and ars that was to become standard in Greek and in Latin is reached. For him, something may happen naturally, by chance, or by art. ${ }^{34}$ The artist (artifex) usually strives to produce a work (हैpyov, opus), again like our 'technology' and unlike our 'science'. This connotation continues into early modern times: a healthy patient in the ars medica, the 'stone' in the ars alchemica, or a 'work' may be a piece of art - it would seem that our modern concept of art is derived from this emphasis on the 'work'. This connotation is absent from scientia, whose aim is pure knowledge for its own sake. But ars is not the blind fashioning of a work; it proceeds with $\lambda$ óyoৎ (Aristotle, De partibus animalium I.1.16, 640a3132):

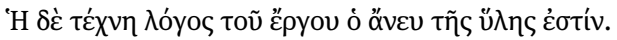

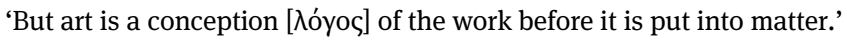

In the wake of Aristotle, Lausberg (1990: 26) can present the following definition:

34 Lausberg: 'Ein geordneter, auf Vollkommenheit zielender Vorgang kann von Natur aus

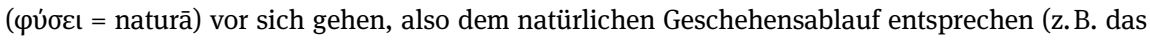
Wachsen eines Baumes). Entspricht er nicht dem natürlichen Geschehensablauf, so kann er durch Zufall ( túxn = casu) oder durch eine von einem vernünftigen Wesen (Mensch) planvoll ins Werk gesetzte Handlung ( $\tau \varepsilon \dot{\chi} \chi \eta \eta \eta$ arte) zustandekommen' ('An orderly process aiming at perfec-

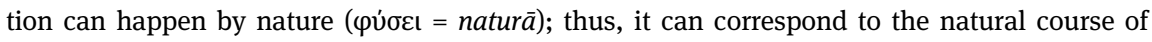
events (e.g. the growing of a tree). If it does not correspond to the natural course of events, it can

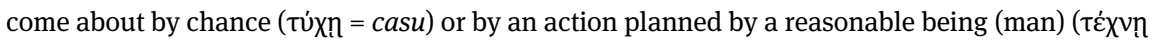
= arte)'; 1990: 25). 


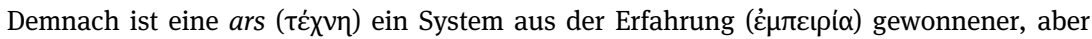
nachträglich logisch durchdachter, lehrhafter Regeln zur richtigen Durchführung einer auf Vollkommenheit zielenden, beliebig wiederholbaren Handlung, die nicht zum naturnotwendigen Geschehensablauf gehört und nicht dem Zufall überlassen werden soll.

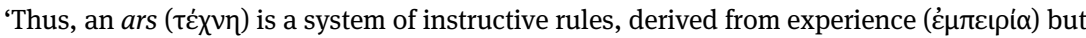
subsequently logically elaborated for the correct execution of an action aiming at perfection and repeatable at will, one that does not belong to the natural course of events and that should not be left to chance.'

Later on, however, and possibly as a consequence of Aristotle's usage, the word $\tau \varepsilon \dot{\chi} \chi v \eta$ ars often also implies a craft of a practical, economically interesting kind, as can for instance be seen in the later Roman Empire in Philostratus (after AD 217), where the philosopher and sage Apollonius of Tyana, while arguing before Domitian's court in his defence against the charge of wizardry, stresses that his art does not earn him money (Vita Apollonii VIII.7, ed. Mumprecht, pp. 862-864):

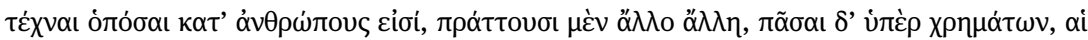

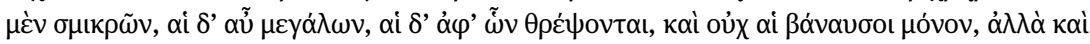

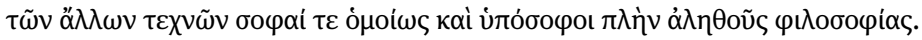

'All the arts that can be found among men somehow or other producing something do it for money - some for little, some for much, some offer a livelihood, not only the manual ones but also the erudite and nearly erudite ones [نंróøo sophy.,35

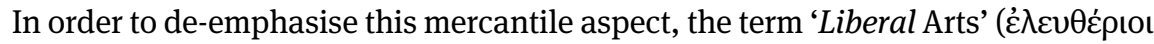
$\tau \varepsilon \dot{x}$ vol, artes liberales) came into use. ${ }^{36}$ Such Liberal Arts are often opposed to artes mechanicae (for practical, mechanical crafts involving the earning of money). The difference between scientia and ars seems to get further weakened in Late Antiquity. ${ }^{37}$ In the Middle Ages these liberal, disinterested, arts become nearly synonymous with scientia/disciplina, especially for the mathematical artes

35 The sentence is complicated; the word úróoo crafts on the one hand and the Liberal Arts on the other. Of the latter the text mentions later poet-

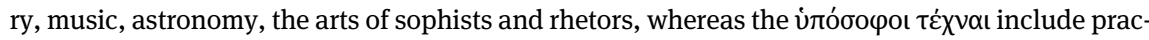
tical but not 'vile' occupations, such as painting, sculpture, navigation, agriculture.

36 See Hadot (1984); chap. 8 below.

37 See Meißner: 'Die Unterscheidung zwischen technischen (Mechanik, Medizin) und theoretischen Wissenschaften, die die Wissenschaftgeschichte der klassischen und hellenistischen Zeit prägte, relativiert sich in der Spätantike' ('The distinction between technical (mechanics, medicine) and theoretical sciences, which characterised the history of science in the classical and Hellenistic periods, is relativised in Late Antiquity'; 1999: 340). But we have seen that this difference was not so clear-cut in classical times either, especially in Aristotle. 
liberales (quadrivium), which have never been concerned with an opus. In general, the relationship between ars and scientia continues to vary between authors, but on the whole ars remains the more practical and thus less esteemed endeavour, one that may lead the way for practical concerns, ${ }^{38}$ while scientia remains more based on $\theta \varepsilon \omega \rho i \alpha /$ contemplatio, disinterested study.

Some later attempts at definition will now be examined. The late antique grammarian Audax writes with the grammatical art in mind (Excerpta de Scauro et Palladio, ed. Keil, vol. 7, p. 320):

Ars quid est? Rei cuiusque scientia ad utilitatem delectationemque tendentis usu uel ratione comprehensa.

'What is art? The acquisition of certain knowledge about something which has aims of usefulness and enjoyment, a practical and a rational aspect being included.'

A probably somewhat later grammar, the Victorini sive Palaemonis ars (ed. Keil, vol. 6, p. 187), understands ars in a wider context: for this author, ars involves activities purely of the mind (roughly 'sciences'), purely of the body ('gymnastics'), or of both ('applied sciences'):

\begin{abstract}
Ars quid est? Vnius cuiusque rei scientia. ${ }^{39}$ Artium genera quot sunt? Tria. Quae? Sunt quaedam animi tantum, quaedam corporis, quaedam animi et corporis. Quae sunt animi tantum? Hae sunt, poetice, musice, astrologice, grammatice, rhetorice, iuris scientia, philosophia. Quae sunt corporis? Iaculatio, saltus, uelocitas, oneris gestamen. Quae sunt animi et corporis? Ruris

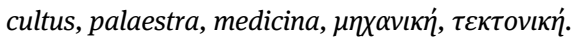

'What is art? The acquisition of knowledge [scientia] about anything. How many kinds [genera] of arts are there? Three. Which ones? Some are of the mind only, some of the body, some of the mind and the body. Which ones are only of the mind? Those are the sciences of poetics, music, astrology/astronomy, grammar, rhetoric, law, and philosophy..$^{40}$ Which ones are of the body? Throwing, jumping, swiftness, carrying of burdens. Which ones are of mind and body? Agriculture, wrestling, medicine, mechanics, carpentry.'
\end{abstract}

Our conclusions about the relationship between scientia and ars are explicitly voiced in a later mediaeval author, a Ps-Bede whose floruit is unclear, commenting on the Ethica Nicomachea passage quoted above. Unfortunately, many of the spurious works of Bede have hardly been studied, and it is often impossible even

38 See Meißner, who speaks of ‘handlungsleitendes Wissen' ('action-guiding knowledge’; 1999: 11).

39 For this definition, cf. Cassiodorus, Institutiones II, praef. 4, ed. Mynors, p. 91.

40 Their number is seven, as in the later usual group of Liberal Arts, but they differ greatly; see chap. 8 below. It is interesting to note that these 'sciences' and philosophy are all artes for this author. 
to tell what century they belong to. The text shows Aristotelian usage of scientia in many definitions (PL 90.968C): ${ }^{41}$

Ars et scientia distinguuntur (VI Ethic.): Debet intelligi capiendo scientiam stricte solum pro habitu speculativo, et etiam capiendo artem stricte solum pro habitu practico. Sed capiendo aeque communiter tam pro habitu practico quam speculativo, tunc non distinguuntur.

'Art and science are distinguished (Ethica Nicomachea VI): strictly speaking, science must only be understood if there is a theoretical character, and similarly art strictly only in case there is a practical one. But seizing upon equally the practical and the speculative character, they are not distinguished.'

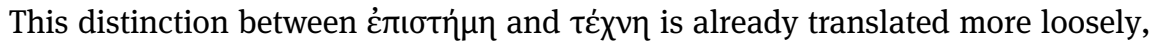
but tellingly, by Vitruvius, ${ }^{42}$ where the former corresponds to ratiocinatio and the latter to opus, in other words again respectively to theoretical understanding and to practical science producing a 'work'. There are also other nuances of difference: thus, according to Menuet-Guilbaud (1994: 84) for Cicero ars - among other meanings - means a 'science particulière' ('particular science'), whereas discipli$n a$ means the 'contenu d'un enseignement, matière enseignée' ('the content of teaching, taught subject-matter'). The latter is the more specialised term for Cicero (88).

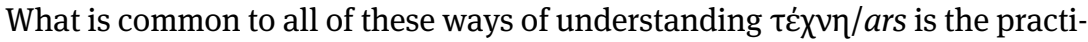
cal character of producing a work, except for the Liberal Arts. The terms can be seen as another ancestor of our 'science': in the Middle Ages, artes (liberales) are often close to our 'science', but in the Scientific Revolution (see chap. 13 below) of early modern times, which emphasises the importance of empiricism and experimenting - things that would traditionally be at best marginal for scientia but pertain to the more intellectual artes - the differences are further blurred. Only in post-Latin times have the terms 'science' and 'art' parted ways quite neatly.

In part 2 of this book, it will become clear that in Roman and early mediaeval times 'science' was largely seen as part of the general, higher education of free men, not specialist work, so the sciences are often called artes liberales, but also litterae or more clearly disciplinae litterarum. These 'letters' already contained more than literature for Cicero, who uses combinations such as litterarum scientia, litterarum cognitio, or nescire litteras (meaning 'to be without a liberal educa-

41 No information about this certainly late florilegium (twelfth or thirteenth century?) can be found in Jones (1939) or in the online ALCUIN portal at the University of Regensburg (https:// www-app.uni-regensburg.de/Fakultaeten/PKGG/Philosophie/Gesch_Phil/alcuin/work.php? $\mathrm{id}=20655)$. The Aristotelian passage intended may be Ethica Nicomachea X.10, 1180b13-23.

42 De architectura I.1.15, ed. Fensterbusch, p. 32. 
tion' and contrasting with scire litteras). ${ }^{43}$ Cicero's terms studium litterarum and scientia litterarum remain common throughout the Middle Ages.

\section{iotopía - historia}

\$5 This is a typically Ionian term (in the form iotopin) and thus contrasts with the

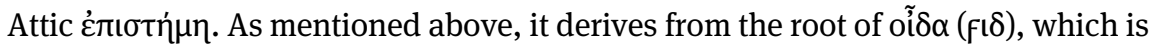
the same root present in German wissen ('to know') and Latin video ('to see'). A nomen agentis I $\sigma \tau \omega \rho$ exists already in Homer in the juridical context of '(eye-)witness'. From this a verb iotopé $\omega$, first and profusely attested in Herodotus, is formed, originally as 'to be an eye-witness'; ${ }^{44}$ iotopi $\alpha$ is thus the researching of an event through eye-witnesses. The word was also used in some contexts by Aristotle (some twenty-eight times), especially for mostly descriptive scientific activities, for which

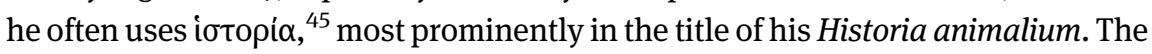
interpretatio romana will find no suitable Roman word to translate this Ionian concept (just as English has not), and merely transliterates it as historia. ${ }^{46}$ There was a similarly formed word in Latin, speculatio, also from a verb meaning 'to spot' or 'to see' like oî $\delta \alpha$, but this word had already become the usual Latin term for $\theta \varepsilon \omega p i \alpha$. Apparently, the word iotopin could in early times stand for 'science' in general. We read in Iamblichus (De vita Pythagorica 18.89, ed. Klein, p. 52):

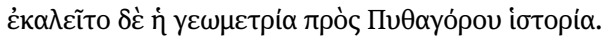

'Geometry was called íotopí by Pythagoras.'

But usually, iotopi $\alpha /$ historia has - in contrast to the other words for 'science' - a tendency to imply a kind of knowledge of 'historical' facts, that is, an emphasis on their temporal development and, often, their uniqueness: it tends to describe them more than to explain them from first principles..$^{47}$ Both these points separate

43 Respectively: Brutus 42(153), ed. Martha, p. 53; De oratore III.32(127), ed. Kumaniecki, p. 310; Brutus 74(259), ed. Martha, p. 93; De finibus II.4(12), ed. Moreschini, p. 38.

44 See Snell (1924: 63). Von Fritz translates iotopí with 'Augenscheinnahme' ('visual inspection'; 1952: 202).

45 See further Floyd (1990).

46 In contrast, German has its own term Geschichte, an abstract to geschehen meaning literally 'what has been happening'. Clearly, the term approaches 'history' from a rather different angle, that of res gestae. See Grimm (s.v. 'Geschichte', 3b). The irregular feminine gender (nouns with the collectivising prefix $\mathrm{Ge}$ - in German are otherwise neuter) is occasionally already attested in Luther; it may well be influenced by the gender of Latin historia.

47 Schütze (2000: 25-26) differentiates four meanings of historia - in rough paraphrase: mere description (as opposed to demonstration), a notitia particularis (as opposed to a theoria generalis), 
such knowledge from غ̇лıбтn $\mu$, which is of general things that always (or 'for the most part', as Aristotle cautiously tends to add) hold true. ${ }^{48}$

In general, however, both historia and scientia can be seen as typical, roughly contemporary discoveries of the Greeks, both meaning to get as much and as certain knowledge about something as possible. ${ }^{49}$ If the difference between them is only that historia does not use first principles and can apply to specific cases, a wider usage of this term than our 'history' naturally follows. The topics can be any singular, non-deducible cases, such as animals in Aristotle's Historia animalium, or even nature as a whole, as for Pliny's Naturalis historia. Occasionally, Aristotle

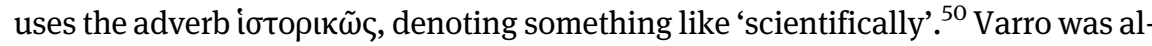
ready clearly aware of this same difference when he compared invented and grammatically derived words (De lingua latina VIII.1(6), ed. Goetz \& Schoell, p. 126):

ad illud genus, quod prius, historia opus est: nisi discend[end]o enim aliter id non pervenit ad nos; ad reliquum genus, quod posterius, ars: ad quam opus est paucis praeceptis quae sunt brevia.

'For that kind [words "invented" by impositio], historia is required, without learning them they do not reach us; for the other kind, the second one [words derived by declinatio], ars is required. For this work only few and short rules are required. ${ }^{51}$

Thus, historia treats singular cases, whereas ars/disciplina/scientia is general and rule-based; the ars alluded to here is, of course, ars grammatica. In early modern times, the difference between apodictic Aristotelian knowledge as scientia and more descriptive knowledge as historia will continue to be felt: botany and zoology will still be seen as 'natural history', in German as Naturkunde, ${ }^{52}$ although they de-

the recounting of deeds (narratio rei gestae), and observation of facts. He follows Goclenius, Lexicon philosophicum (Francofurti, 1613), p. 626.

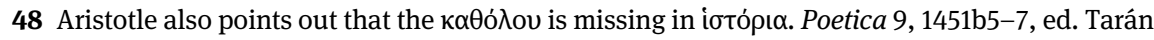

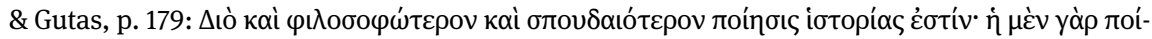

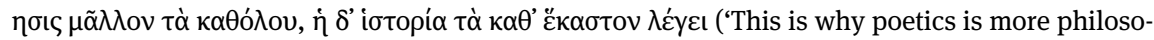
phical and serious than history. Poetics relates more the general, history the specific').

49 e.g. von Fritz (1967: 5), who emphasises the critical approach in both. See also von Fritz (1952). See chap. 24 below on whether 'science' is a Greek invention.

50 De generatione animalium III.8 (757b35). LSJ translate the adjective as 'exact, precise, scientific'.

51 Thus, Varro would say that in the strife between sound-law Neogrammarians and their opponents with the slogan 'chaque mot a son histoire' ('each word has its own history') both approaches are valid depending on the word. But it seems that Varro (and other premodern authors) rather underestimated the complexity of the rules involved.

52 Kunde from Old High German kundeo ('witness') denotes a rather wider form of 'testified' knowledge than Wissenschaft. 
velop as sciences in the modern sense of the word. The Scientific Revolution, however, will mix these two categories again by taking into account observations of unique events ('idiographic science'), ${ }^{53}$ from which a science may progress from description to finding underlying patterns and thus become explanatory, as, for instance, happened to botany and zoology with - at the latest - the advent of evolution theory and twentieth-century genetics. In Latin the word historia soon also acquires a broader meaning of any 'account, narrative, tale' (whence the English word 'story'). ${ }^{54}$ The word finally ends up as 'history' in English, again getting closer to Herodotus, who, however, used only one specific nuance of the word, that of the iotopí $\alpha$ of peoples.

Further complicating things, some later authors see historia (in this narrow sense of 'historiography') itself as approaching an ars, as does for instance Hugh of St Victor in the twelfth century. ${ }^{55}$ Other writers seem to sense a personal, so to speak 'subjective', component (its topic being within us, not in 'external' nature), for instance the fifteenth-century theologian Lambertus de Monte, Expositio De anima (Cologne, 1498), fol. 4ra:

Notandum, quod Aristoteles vocat hanc scientiam de anima 'historiam' [...] quia sicut in historiis traduntur aliqua quae in nobis experimur, ita scientia de anima est de his quae in nobis ita esse naturaliter experiuntur.

'It is to be noted that Aristotle [in 402a4] calls this science of the soul historia [...] because as in history books things that we experience within us are handed down, so the science of the soul concerns itself with such matters that are naturally experienced within us.'

Historiography was thus often seen as merely rhetorical, literary, or didactic in nature and had no fixed place among the mediaeval sciences. ${ }^{56}$ It had its distinctive stylistic ideals, and an oratorial style was expected to be used in writing historiography. ${ }^{57}$ But in early modern times, there was a renewed discussion about whether history can be an ars or even a scientia. One of the authors writing about this topic was Gerardus Johannes Vossius (1577-1649), Ars historica 2-4, pp. 5-14, opting for the former:

53 As von Fritz (1967: 3) calls it.

54 Loci in Lewis \& Short (s.v.); earliest usages already in Plautus. See also Cizek (1995: 12-13).

55 Didascalicon III.2, ed. Offergeld, pp. 216-228. More exactly, he speaks of an appendens artium, as it is not part of the traditional seven (see chap. 10 below).

56 More details in Melville (1986-1987: 157-172).

57 e.g. Cicero, De legibus I.2(5), ed. Plinval, pp. 3-4: [historia] quippe cum sit opus, ut tibi quidem uideri solet, unum hoc oratorium maxime ('since as at least you have always held, this endeavour [history] is the most oratorial one'). 
QUam notum est historiae nomen, tam pene ignotum est plurimis, organicam esse disciplinam, quae Historice vocetur. [...] Scientia vero non est, ut tum finis indicat, tum obiectum. Nam historice discitur, ut historiam legitime contexamus; scientia vero est, non operationis, sed sciendi gratia.

'As well known as the name "history" may be, it is nearly unknown to many that there is also

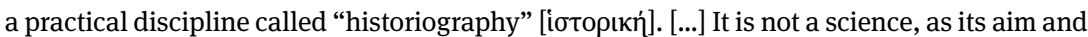
its object indicate. For historiography is learned in order that we may compose history books; but a science does not strive after a work, it is for acquiring knowledge only. ${ }^{58}$

Other authors, such as Sebastiano Maccio (De historia, Venetiis, 1613, chap. 10; quoted disapprovingly by Vossius, Ars historica 4, p. 17) had indeed gone further in demanding the status of a scientia for historia. It has been argued that historiography becomes a scientific discipline only in nineteenth-century German Historismus, ${ }^{59}$ when textual criticism and source criticism were methodologically applied in order to pinpoint historical 'laws'. Others are of the view that it has never become a scientific field at all. But some writers of Antiquity and the Middle Ages were well aware that scientific principles could be applied even to matters that happen only once and belong to historiography in the modern sense, with the aim of reaching the best possible understanding of what happened. More ambitious authors in the antique tradition of great historians, from Hecataeus (fl. 500 BC) and Herodotus (ca. 484-ca. 425) to Thucydides (ca. 460-ca. 400) and Polybius (ca. 200-ca. 118) or Titus Livius (64/59 BC-AD 17) and Cornelius Tacitus (ca. 56-after 117) did - often successfully - look for deeper reasons behind historical developments, and they did think critically and understood motivating forces behind events, all of which led to a deeper understanding of historical events. How good, scientific historiography is to be done is already pointed out in detail by Lucian (Quomodo historia conscribenda sit 47-48, ed. MacLeod, vol. 3, p. 314): ${ }^{60}$

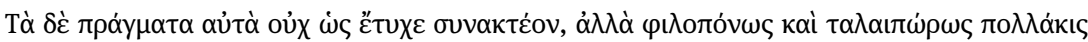

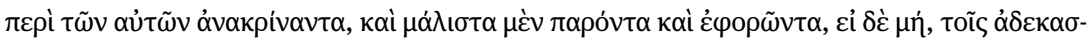

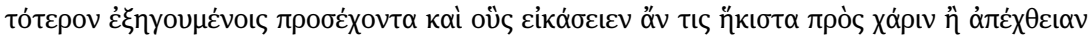

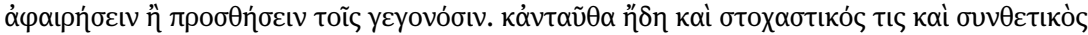

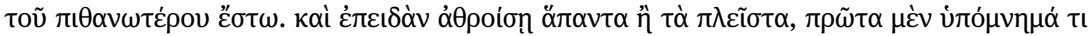

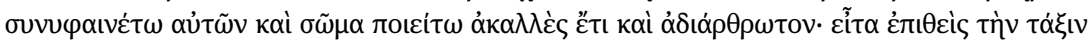

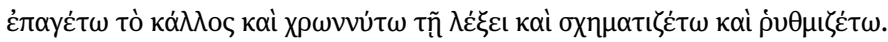

58 Vossius thus applies the standard distinction between ars and scientia. For the general (widespread) discussion on the nature of historia in early modern times, see Grafton (2007).

59 e.g. by Korenjak (2016: 199).

60 On historia as a methodological science in the Middle Ages, see Schulz (1909), who shows that all of the points mentioned by Lucian were reiterated by mediaeval historians; on historia's relation to the Liberal Arts, see Wolter (1976). 


\begin{abstract}
'The facts should not be assembled at random, but he [the historian] must examine them painstakingly and often in a manner full of hardship, and if possible be an eye-witness and observe. If he cannot, he should heed the more impartial witnesses and those who would least seem to leave aside or add facts out of favour or malice. Then he should be shrewd and skilful in composing a story as plausible as possible. When he has assembled all or most of the data, he should first compose notes from them and he should make a body of material as yet unadorned and without organisation. Only then, after arranging it in an orderly manner, he should adduce beauty and adorn it with phrasing and figures and rhythm.'
\end{abstract}

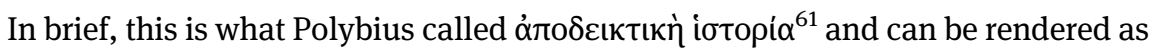
'scientific historiography'. The Middle Ages and early modern times also had historians who worked very much according to such principles, for instance William of Malmesbury (ca. 1095-ca. 1143), whereas other historians (e.g. Liutprand of Cremona, ca. 920-972) instead wrote propagandistic history that clearly took sides. In general, indeed, it was only in the nineteenth century that scientific rigour and clearly defined methods became standard for historiography, which was now present as a discipline at universities, but many other sciences became much more rigorous during or after the Scientific Revolution too. ${ }^{62}$ Introductions to history's methodology often concluded that history was indeed a science. For instance, Feder (1924: 12-14) argues that historiography is a science despite Aristotle's insistence that sciences treat only 'das Allgemeine' ('the general'; 12), for it seeks a genetic and causal understanding of the past. Boyer sums the discussion up (Cursus philosophiae, Logica maior q. 4, a. 4, §1.II, vol. 1, p. 295):

De alia quaestione, minoris quidem momenti, an scilicet historia sit proprie scientia, alii aliter opinantur.

'On this other question, which is of lesser moment, whether historiography is a proper science, some think this and some that.'

Even though there would thus seem to exist quite strong arguments for including historiography among the sciences, it is only marginally treated in this book, as it differs conspicuously in several respects from other sciences, among them in its language, as a sample of texts below (chap. 20) will show. Indeed, as the quoted passages have suggested, even in Antiquity historiography had its own style, quite in contrast to most other scientific disciplines. In Antiquity and the Middle

61 Historiae II.37, ed. Büttner-Wobst, vol. 1, p. 169.

62 Châtelet is thus too sweeping when he states: 'L'histoire est savoir. Elle n'est savoir historique - on veut dire par là: savoir qui a la possibilité d'apporter les preuves de sa véracité - que depuis le xix ${ }^{\mathrm{e}}$ siècle' ('History is knowledge. It is only since the nineteenth century that it has been historical knowledge - by which we mean knowledge that entails the possibility of adducing proofs of its veracity'; 1962: 15). 
Ages, the connection between scientia/disciplina and historia is rarely pointed out explicitly.

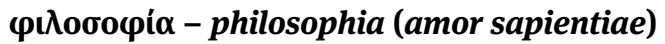

\$6 This word describes what the $\varphi$ ı $\lambda$ óoo parently coined by - according to non-contemporary ancient sources - Pytha-

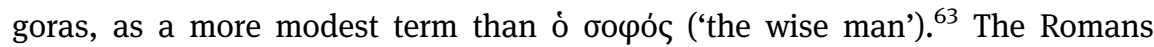
loaned the Greek word as philosophia, only rarely ${ }^{64}$ translating it as amor sapientiae. One might be tempted to see a development from 'wise men' through philosophers to scientists, but, reality is - as so often - rather more complicated. Only some general points about the complicated epistemological question of the shifting relation between philosophy and science can be discussed here. It is clear that this relation changed over time and that there are several mutually exclusive posi-

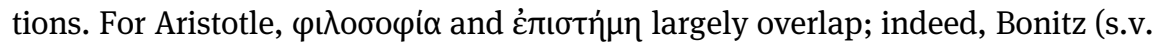
$\varphi \iota \lambda о \sigma о \varphi і \alpha)$ explains the former as investigatio; scientia, cognitio; philosophia. Aristotle distinguishes a first and a second philosophy, the former what we would call metaphysics today, the latter roughly natural science (Metaphysica Z11, 1037a13-20): studying things that can be perceived by the senses. In Antiquity $\varphi$ ı sising the more 'practical' and global connotations of the philosophers' own way

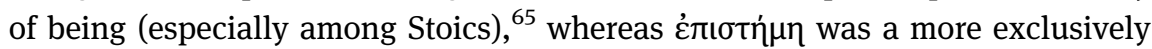
theoretical endeavour divided into various disciplines. Among the Roman philosophical schools, especially the Stoics, it was customary to divide philosophy into three disciplines: physics, logic, and ethics. The first of them corresponds more or less to our natural science, but the last of them was by far the most esteemed one. ${ }^{66}$ In Roman times, the term philosophus was often used as an honorific for

63 Diogenes Laertius, De vita philosophorum I.12, ed. Long, vol. 1, p. 5, and Cicero, Tusculanae disputationes V.3(8-9), ed. Fohlen, pp. 109-111, who translates the concept as sapientiae studiosus. See further Burkert (1960).

64 e.g. Augustine, De ordine I.32, ed. Doignon p. 156.

65 '[I]l est utile de rappeler le sens "totalitaire" de la "philosophie" chez tous les penseur païens: la philosophie est pour eux la synthèse du savoir, le système général des sciences, la sagesse intégrale vers laquelle est bandé tout l'effort de la pensée humaine' ('It is useful to recall the "totalitarian" sense of "philosophy" in all pagan thinkers: for them, philosophy is the synthesis of knowledge, the general system of sciences, the integral wisdom to which all the effort of human thought is directed'; van Steenberghen 1966: 55).

66 The three parts of philosophy, e.g. in Zeno of Citium §45, ed. von Arnim, vol. 1, p. 15 (= Dio-

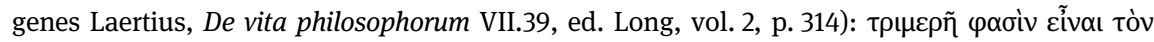

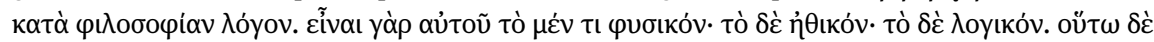


men of letters holding some important public office and usually pertaining at least loosely to one of the philosophical schools. ${ }^{67}$ On the other hand, the polyse-

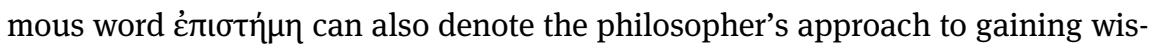

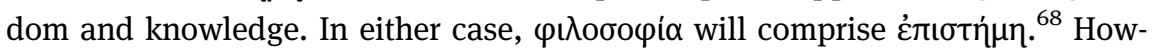
ever, on the other hand, philosophia sensu stricto can be seen as a scientific discipline, as is often the case today. ${ }^{69}$ Thus, philosophia can be seen as an ars $^{70}$ or a scientia. Thomas Aquinas states in his Sententia libri Metaphysicae (IV.4.7, ed. Spiazzi, p. 574):

Licet autem dicatur quod philosophia est scientia, non autem dialectica et sophistica, non tamen per hoc removetur quin dialectica et sophistica sint scientiae.

'Although it may be said that philosophy is a science, not so dialectic and sophistic, although by this it will not be denied that dialectic and sophistic can be sciences. [He goes on to state in what way the latter two can also be considered scientiae.]'

Even in the twentieth century, the neo-scholastic Cursus philosophiae by Carolus Boyer still presents the following definition (Introductio 2, a. 2, vol. 1, p. 46):

[P]hilosophiae definitio, quae communiter recipitur: Scientia rerum per ultimas causas naturali rationis lumine comparata.

'The definition of philosophy that is commonly used: the knowledge [scientia] of things through their highest causes, attained by natural reason. ${ }^{, 71}$

A possible precursor to this point of view can be seen in Isidore, for whom philosophia is the culmination of science (Etymologiae II.24.9, ed. Marshall p. 107; see chap. $2 \S 4$ above):

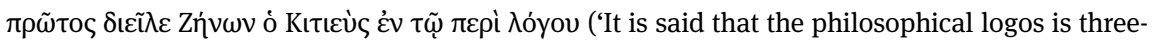
fold. It contains physics, ethics, logic. Zeno of Citium first made this distinction in his work On the Logos').

67 Haake (2017) studies the use of philosophus on Roman inscriptions. He finds the term as an honorific much more commonly in the Eastern, Greek, part of the Empire, where the polis structure, seen by Haake as the natural habitat of the philosopher (413), was still partly intact. Interesting statistical research on these schools has been performed by Goulet (2017).

68 See Hadot (1979).

69 Compare the list of sciences drawn from Schurz in chap. $1 \S 7$, which includes philosophy.

70 Thus Seneca, Naturales quaestiones I, proem., ed. Hine, p. 1: Quantum inter philosophiam interest, Lucili uirorum optime, et ceteras artes, [...] ('As much as there is difference within philosophy, Lucilius, best of men, and within other arts [...]').

71 The addition 'natural' is meant to distinguish it from theology. Similarly Cursus philosophiae, Intro. 2, a. 2, §2.I, vol. 1, p. 48: Philosophia cum ceteris scientiis convenit in quantum et ipsa est vera scientia, scilicet ordinatur ad cognitionem certam obtinendam, de qua rationem reddere possit ('Philosophy accords with other sciences in that it too is a true science, viz. it is disposed toward the attainment of certain knowledge for which it can provide the reason'). 
Philosophia est ars artium, et disciplina disciplinarum.

'Philosophy is the art of arts, the science of sciences.'

Although the Greeks did not keep what we now call 'philosophy' and 'science' neatly apart, already around $500 \mathrm{BC}$ there were men who engaged exclusively in the one or the other - exclusively philosophers (e.g. Heraclitus or Zeno) and exclusively scientists/scholars (Hecataeos of Miletus, Hippocrates of Chios, Theaetetus). Of course, some also did both, such as Parmenides, Democritus, and, later on, Aristotle.

Derived from the Stoic physica, natural science was often called naturalis philosophia in the Middle Ages and early modern times instead of naturalis scientia. ${ }^{72}$

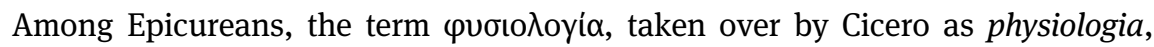
was used in the same sense. In fact, traces of this view were to remain in place until recently: German-speaking universities housed the natural sciences in a Philosophische Fakultät II (adding the number 'II' to differentiate from the human sciences and philosophy proper). ${ }^{73}$

The definite division between natural science and philosophy takes place as late as in the eighteenth and nineteenth century; Wilhelm Dilthey (1833-1911), in particular, builds the foundation for a new, narrower meaning of philosophy. ${ }^{74} \mathrm{In}$ the wake of the great successes of the 'hard' sciences since the Scientific Revolution (see chap. 12 below), some polemical scientists have insisted that philosophy is not a scientific enterprise at all and concluded that it is therefore of little value. ${ }^{75}$ Paulsen (1877: 35$)$ formulates this point especially drastically by comparing philosophy metaphorically to idlers and robbers:

72 Corpus Corporum (as of 1 March 2016) has 24 occurrences of the former versus 40 of the latter before Aquinas, and 133 and 347 before AD 1600. Thus, naturalis philosophia is losing ground in the Late Middle Ages. There seems to be an increased awareness of scientia as distinct from philosophia.

73 This name persists to this day at some universities, such as the Humboldt University in Berlin.

74 See further Wieland (1970: 16).

75 For instance, Zhmud, writing on this topic, does not define what he means exactly by philosophy and science; he just states an 'epistemologische Andersartigkeit [...], wissenschaftliche Probleme können erfolgreich gelöst werden, philosophische Probleme sind prinzipiell unlösbar' ('epistemological difference [...], scientific problems can be solved successfully, philosophical problems are unsolvable in principle'; 1994: 1). Zhmud seems to take philosophy mostly as metaphysics, which in turn he sees as a kind of depersonalised mythology, leading to famous 'pre-Socratic' statements that everything is water or fire or infinity. His disdain of philosophy on the one hand and his approval for practically applicable science on the other may be connected with his materialist Soviet background. In other publications, he shows a general scorn for myth and religion. 
So möge sie in ähnlicher Weise der Wissenschaft vorausgehen, wie etwa Räuber und allerlei Arbeit und Ordnung hassendes Gesindel in Amerika als Pioniere der Zivilisation dem Ackerbauer und Städtegründer vorangehen.

'It [philosophy] may precede science similarly to how robbers and all kinds of work- and order-hating rabble precede the farmers and founders of cities as pioneers of civilisation in America.'

Others emphasise today the personal character of philosophy in improving the philosopher, or see it as a human science.

\section{$\pi \alpha ı \varepsilon i ́ \alpha, \pi \alpha i ́ \delta \varepsilon v \sigma ı \varsigma$ - eruditio}

\$7 Although $\pi \alpha ı \delta$ í $\alpha$ can be translated as eruditio in Latin, ${ }^{76}$ there is no direct correspondence for these words. In Greek $\pi \alpha เ \delta \varepsilon i \alpha,{ }^{77} \pi \alpha i \delta \varepsilon v \mu \alpha$, and $\pi \alpha i \delta \varepsilon v \sigma ı \varsigma$ are similar terms, all of them meaning literally 'what is done with the young (in order to cultivate them)'. The first denotes the entire process and the resulting state, the second that which is taught in order to reach it, and the third the action and means of achieving it. The Latin term eruditio is similar in meaning, although it looks at the situation from the result ex negativo: literally as 'de-savagisation'. All of these terms emphasise more the state of education one attains through learning than science proper. For Aristotle, mere general education ( $\pi \alpha t \delta \varepsilon i \alpha)$ is a kind of

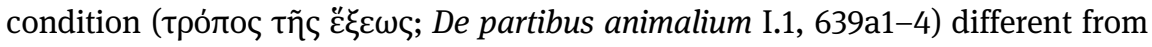

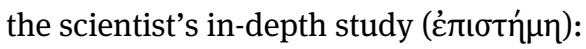

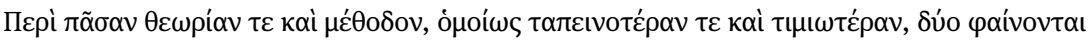

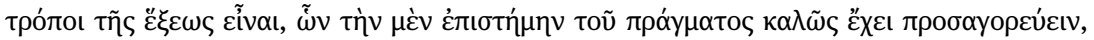

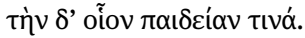

'For all theoretical and methodological endeavours, be they humbler or worthier, there seem to be two kinds of conditions. The one may rightly be called a scientific knowledge of a thing, the other [merely] like education.'
}

This $\pi \alpha ı \delta \varepsilon i \alpha$ - although not reaching scientific standards - is still addressed as a $\theta \varepsilon \omega$ pí $^{\prime}$ and $\mu \varepsilon \theta_{0} 0 \delta$ o to gain insight. It is reserved for free men, as is stressed in Politica VIII.3, 1338a:

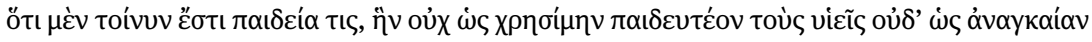

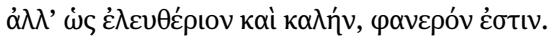

76 Hedericus \& Pitzger (s.v. $\left.\pi \alpha \_\delta \varepsilon i \alpha\right)$ offer as translations: institutio, instituendi ratio, doctrina, eruditio, disciplina, whereas they translate $\pi \alpha \dot{\delta} \delta \varepsilon v \sigma \iota \varsigma$ as ipsa erudiendi actio.

77 On this important concept, see the classic Jaeger (1934) and more recently Kühnert (1961). 
'It is clear that there exists some kind of education which is not taught as practically useful to sons, not as necessary, but as something free and beautiful.'

It will become clear in chapter 9 below how this $\pi \alpha$ เocia gave rise to the expres-

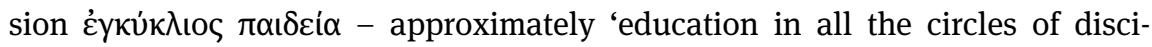
plines' - and would in turn lead to the genre of natural histories and finally to the 'encyclopaedia'. Its canon led to the artes liberales, which are, again, reserved for free men.

\title{
$\delta \mathrm{t} \alpha \sigma \kappa \alpha \lambda i \alpha^{\alpha}$ - doctrina
}

\$8 Doctrina is the term often used for the teaching of science and other learning. The word - derived from doceo ('to teach') - corresponds to $\delta$ i $\delta \alpha \sigma \kappa \alpha \lambda i \alpha$ ('learning'), which is likewise derived from the word for 'to teach' $(\delta เ \delta \alpha \dot{\sigma} \sigma \omega) .{ }^{78}$ Semantically similar words in German are Lehre and Gelehrsamkeit, or English 'learning' These words tend to be used for the more or less dogmatic content taught to pupils which can become the foundation on which to build further scientific studies. In pagan Antiquity the word's semantics already at times approach our 'science', for instance in Pliny, Naturalis historia (VIII.17(44), ed. Ernout et al., vol. 8, p. 38):

\begin{abstract}
Alexandro Magno rege inflammato cupidine animalium naturas noscendi delegataque hac commentatione Aristoteli, summo in omni doctrina viro, aliquot milia hominum in totius Asiae Graeciaeque tractu parere iussa, omnium quos venatus, aucupia piscatusque alebant quibusque vivaria, armenta, alvaria, pisciniae, aviaria in cura erant, ne quid usque genitum ignoraretur ab eo.

'King Alexander the Great, who was inflamed with a desire to know the natures of animals, assigned this study to Aristotle, the greatest man in every science. He placed thousands of men in every region of Asia and Greece under his command, comprising all those who are nourished by hunting, fowling, or fishing, or who had the care of parks, herds of cattle, the breeding of bees, fish-ponds, and aviaries, in order that he should not miss any such matter.'
\end{abstract}

The twelfth-century translator James of Venice, who translates Greek verbum de verbo, translates the beginning of Aristotle's Analytica posteriora as (ed. in Aristoteles Latinus 4.1-4, p. 5):

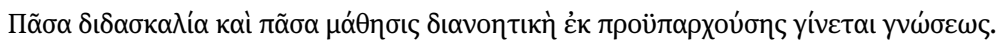
Omnis doctrina et omnis disciplina intellectiva ex praeexistente fit cognitione.

'All scientific learning and all theoretical science departs from already existing knowledge.'

78 This is an interesting case in which the semantic and etymological correspondences differ: etymologically doceo $=\delta$ ok $\dot{\omega} \omega$, disco $\left(<^{*} d i-d \dot{k}-s \hat{k}-\bar{o}\right)=\delta 1 \delta \alpha \dot{\sigma} \sigma \omega \omega$ (see $L I V$, which, however, proposes a desiderative form of the same root, ${ }^{*} d i-d \hat{k}$-se-). 
This equates doctrina with $\delta เ \delta \alpha \sigma \kappa \alpha \lambda i{ }^{\alpha}$ and disciplina with $\mu \alpha \dot{\theta} \theta \eta \sigma \mathrm{s}$. Isidore, on the other hand, brings mathematica (and thus $\mu \alpha \dot{\theta} \eta \mu \alpha$ ) close to doctrina when he equates it with doctrinalis scientia (Etymologiae III, praef., ed. Gasparotto, p. 3), ${ }^{79}$ in a passage inspired by Cassiodorus: ${ }^{80}$

Mathematica latine dicitur doctrinalis scientia quae abstractam considerat quantitatem.

'Mathematica means in Latin the scientific teaching which considers abstract quantity.'

This usage is occasionally also met later on, as in the twelfth-century al-Fārābi Latinus. ${ }^{81}$ In both cases, doctrina conveys knowledge that is taught and learned. In the Early Middle Ages, when the school aspect of learning becomes central, this term is often used in a sense that approaches that of scientia/disciplina. The PL, with its nearly exclusively late antique and mediaeval Christian texts, contains 197 cases of synonymous use of the kind scientia et/ac/atque doctrina (or vice versa, in all case-forms). There are only 30 such cases for ars and scientia, and even for the near-synonyms disciplina and scientia only 119. In the later Middle Ages, sacra doctrina was to become a common designation for the 'sacred science' of theology.

$\Sigma \pi 0 v \delta \eta \dot{~ a n d ~} \mu \varepsilon \lambda \varepsilon \dot{\tau} \eta \eta$ in Greek and studium in Latin belong to the same semantic province, although these terms are broader. For example, Pliny calls the Numidian King Iuba (Naturalis historia V.1.16, ed. Ernout et al., vol. 5, p. 52) studiorum claritate memorabilior etiam quam regno ('even more memorable by the fame of his scientific studies than as a king'). Georges defines this use as 'das wissenschaftliche Streben, die wissenschaftliche Beschäftigung, das Studieren' ('scientific pursuit, scientific occupation, study'). Of course, studium has a broad spectrum of meaning, more usually of any ‘striving’ after something.

\section{$\mu \varepsilon ́ \theta 0 \delta$ os - methodus}

\$9 Another Greek word that was taken over into Latin as a loanword (like historia and philosophia, encountered above) is $\mu \varepsilon \dot{\theta} \theta \delta$ oc. This Greek word is derived from

79 The theoretically more fitting disciplinaris/disciplinalis is very rare before the High Middle

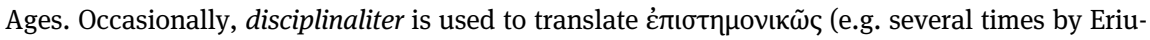
gena). Another late word for 'scientifically' is scientifice, mentioned in $\S 3$ above.

80 Cassiodorus, Institutiones II.3.21, ed. Mynors, p. 130: Mathematica, quam Latine possumus dicere 'doctrinalem', scientia est quae abstractam considerat quantitatem ('Mathematics, which we can call doctrinalis in Latin, is the science that considers abstract quantity').

81 Translation by Dominicus Gundissalvi, prol., ed. Schneider, p. 120. Alongside the four usual sciences of the quadrivium, al-Fārābī adds further mathematical sciences: optics, mechanics, and statics. On this author, see further chap. $10 \S 6$ below. 


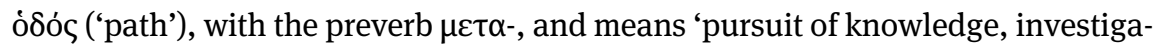
tion'. Its use for a pursuit of other things than knowledge and science is very rare. ${ }^{82}$ Later on, in a clearly derivative way, the word can be used as 'ruse, trick', as in the Septuagint Bible (2 Macc. 13:18). Plato uses the word 26 times, Aristotle 79 times. Bonitz explains Aristotle's usage as via ac ratio inquirendi; in fact, Aris-

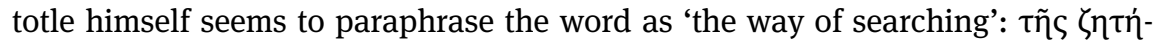

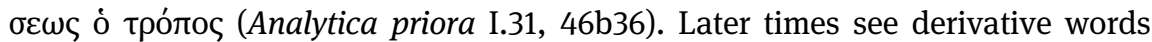
such as $\mu \varepsilon \theta o \delta \varepsilon v \omega \omega$ ('treat or practise by rule or method'; explained by Hesychius, ed. Latte, s.v., as $\mu \varepsilon \tau \varepsilon \dot{\rho} \rho \varepsilon \sigma \theta \alpha \mathrm{l}$ ) or $\mu \varepsilon \theta o \delta \varepsilon i ́ \alpha$ ('craft, wiliness; method of collecting

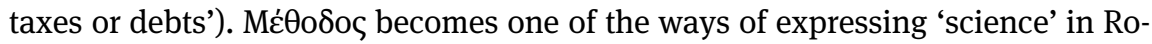
man Antiquity, especially when wishing to stress its systematic character. For example, Nicomachus of Gerasa (Introductio arithmetica 1.1, ed. Hoche, p. 1) writes (meaning men like Pythagoras):

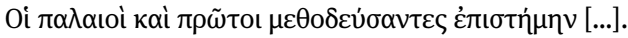

'The ancients who first made knowledge systematic/scientific [...].'

A similar usage is found in Galen. He posits $\lambda$ óyoৎ and $\pi \varepsilon i ̃ \rho \alpha$ as the instruments of

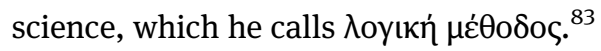

The first author we know of who used the word in Latin is Vitruvius. ${ }^{84}$ Latin finds a similar word in procedura only very late, by borrowing it back from French. ${ }^{85}$ It usually remained confined to legal procedures. In Roman times, there is a medical school called the methodici ( $\mu \varepsilon \theta 0 \delta$ เкоi), ${ }^{86}$ which Celsus calls quidam medici saeculi nostri ('certain physicians of our century'; De medicina 1, prol. 54, ed. Marx, p. 26). They arose as a reaction against and a mediation between the empirici and the dogmatici. ${ }^{87}$ Celsus describes their undogmatic 'method' thus:

contendunt nullius causae notitiam quicquam ad curationes pertinere; satisque esse quaedam communia morborum intueri.

82 Pape defines it as 'das Nachgehen, Verfolgen; wohl nur vom kunstgemäßen, wissenschaftlichen Verfolgen einer Idee, von der wissenschaftlichen Behandlung eines Gegenstandes, u. bes. das geregelte Verfahren dabei, die Methode' ('following, pursuit; probably only for the artistic, scientific pursuit of an idea, for the scientific treatment of an object, and in particular the regu-

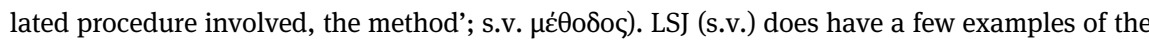

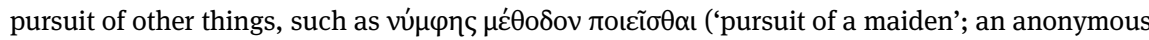

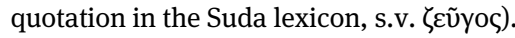

83 De methodo medendi I.8, ed. Kühn, vol. 10, p. 29.

84 De architectura I.1.4, ed. Fensterbusch, p. 24.

85 There are two instances, both from the eighteenth century, in Corpus Corporum.

86 On them, including a collection of their fragments, see Tecusan (2004).

87 On the methodologies of these three schools, see Lloyd (1987: 158-167). 
'they contend that no knowledge of the [ultimate] cause [of a disease] should have influence on cures; and that it is enough to consider some common features of diseases.'

Themison of Laodicea (123-43 BC) seems to have founded this school. Caelius Aurelianus calls it the methodica disciplina ${ }^{88}$ This school's name will be the most common use of the word methodus, which otherwise remains quite in the background, at least until modern discussions of 'methodology' (note the sharp rise in early modern times in table 2 below).

\$10 In order to find out how common the terms considered are in literature in general through the ages, their absolute frequency per thousand words and their frequency classes were determined in table 2 and illustrated in figure 2 . The values for the frequency classes are logarithmic, and low ones entail high frequency. ${ }^{89}$ The numbers were calculated using Corpus Corporum for lemmata in five important time spans; ${ }^{90}$ numbers for the tentative Greek equivalents are also provided, for Greek as a whole (TLG) and for Aristotle, an author who seems especially important for scientific terminology. The most common lemma, which is assigned frequency class 0 , is given at the bottom; either sum or et tend to be the most common.

There are obviously significant differences between Greek and Latin usage as well as within these languages. The frequency classes for these words are two to three classes more common in Latin than in Greek. This may partly be explained by the absence in Latin of the most common Greek word: the article, which is (per thousand words) much more common than the most common Latin word. The absolute values in Latin still tend to be slightly higher than the corresponding ones in Greek.

88 Caelius Aurelianus, Tardae passiones IV.1.6, ed. Drabkin, p. 816.

89 More precisely, frequency classes are a binary measure of how much less often a word occurs than the most frequent word in a language. Thus, a word (say) 16 times $\left(=2^{4}\right)$ less frequent than the most common one in the language in question belongs to class 4 . The precise formula is: $\mathrm{cl}(\#$ word $)=$ FLOOR $\left[0.5-\log _{2}(\mathrm{f}(\#\right.$ word $) / \mathrm{f}(\#$ most frequent word $\left.))\right]$. More details in e.g. Meier (1978).

90 The same samples were used for the benchmark corpora below (chap. 18 §2). See there for details on them. 
Table 2: Absolute values in \%o and frequency classes of key terms for 'science' in general Latin samples from various periods. The values for similar Greek words in general and in Aristotle are given for comparison.

\begin{tabular}{|c|c|c|c|c|c|c|c|c|c|c|c|c|c|c|c|}
\hline \multirow[b]{2}{*}{ scientia } & \multicolumn{2}{|c|}{$100 \mathrm{BC}-\mathrm{AD} 200$} & \multicolumn{2}{|c|}{$200-450$} & \multicolumn{2}{|c|}{$780-900$} & \multicolumn{2}{|c|}{$1100-1220$} & \multicolumn{2}{|c|}{$1500-1820$} & \multirow{2}{*}{\begin{tabular}{|l|} 
Greek \\
غ́mıтń $\mu \eta$
\end{tabular}} & \multicolumn{2}{|l|}{$T L G^{91}$} & \multicolumn{2}{|c|}{ Aristotle } \\
\hline & 0.19 & 8 & 0.30 & 7 & 0.36 & 7 & 0.39 & 7 & 0.24 & 7 & & 0.18 & 10 & 0.85 & 7 \\
\hline disciplina & 0.23 & 7 & 0.22 & 8 & 0.19 & 8 & 0.17 & 8 & 0.08 & 9 & $\mu \alpha \dot{\theta} \theta \mu \alpha$ & 0.05 & 12 & 0.02 & 13 \\
\hline ars & 0.41 & 7 & 0.09 & 9 & 0.08 & 9 & 0.07 & 9 & 0.15 & 8 & $\tau \varepsilon_{X} \chi \eta \eta$ & 0.24 & 9 & 0.27 & 9 \\
\hline historia & 0.13 & 8 & 0.10 & 9 & 0.18 & 8 & 0.11 & 9 & 0.24 & 7 & íторі́ & 0.12 & 10 & 0.03 & 12 \\
\hline philosophia & 0.21 & 8 & 0.05 & 10 & 0.02 & 11 & 0.03 & 11 & 0.11 & 8 & 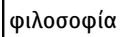 & 0.11 & 10 & 0.06 & 11 \\
\hline doctrina & 0.13 & 8 & 0.31 & 7 & 0.47 & 6 & 0.31 & 7 & 0.65 & 6 & $\delta ı \delta \alpha \sigma \kappa \alpha \lambda i \alpha$ & 0.13 & 10 & 0.02 & 13 \\
\hline eruditio & 0.02 & 11 & 0.03 & 11 & 0.03 & 10 & 0.03 & 11 & 0.03 & 10 & $\pi \alpha ı \delta \varepsilon i ́ \alpha$ & 0.06 & 11 & 0.08 & 11 \\
\hline methodus & 0.00 & 14 & 0.00 & 17 & 0.00 & 16 & 0.00 & 16 & 0.05 & 10 & 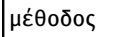 & 0.05 & 11 & 0.07 & 11 \\
\hline Most frequent & & sum & & sum & & sum & & $e t$ & & et & & & $\dot{o}^{92}$ & & ó \\
\hline Total & 1.34 & & 1.09 & & 1.34 & & 1.11 & & 1.55 & & & 0.92 & & 1.41 & \\
\hline
\end{tabular}

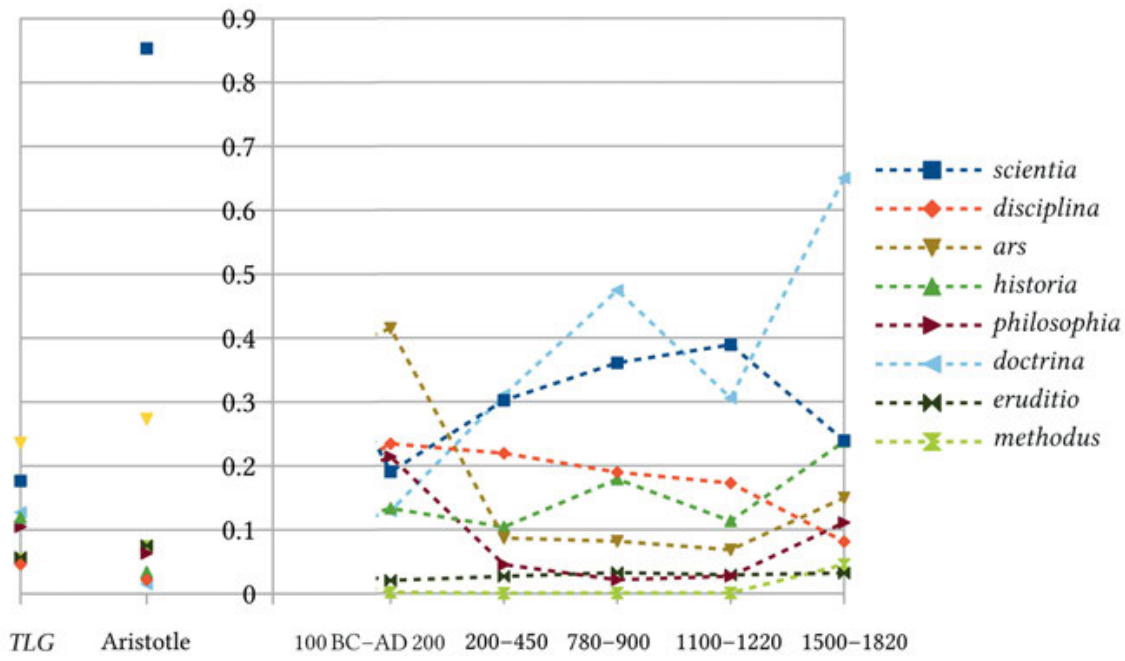

Fig. 2: Distribution of key terms for 'science' in Greek (left) and Latin (right) in \%o. For the Greek terms compared on the left-hand side, see table 2.

$91 T L G$ does not allow time-constrained searches, so only global numbers were used. The numbers for Aristotle are from Corpus Corporum.

92 The most frequent Greek word is the article, which is lacking in Latin (15.5 million in the entire

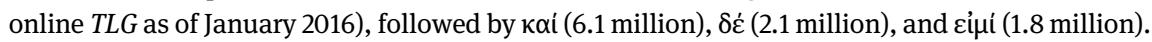


Aristotle, whose importance for the further development of Latin scientific voca-

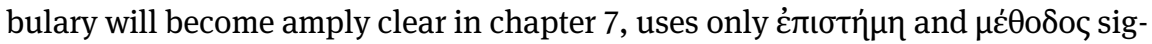
nificantly more frequently than the Greek average; most of the other words he

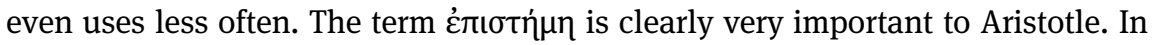
Latin, ars is in Antiquity by far the most common of the studied words; scientia and doctrina become more common over time, the former reaching Aristotle's frequency class early on, but, strangely, its frequency drops again in the sample from early modern times; in contrast, historia becomes more common. The frequency of disciplina stays relatively constant, though in decline. It can be observed that the early modern frequencies are again closing in on the classical ones, in some cases showing these authors' conscious imitatio of Antiquity (philosophia, ars, scientia). The Greek loan methodus becomes nearly as common as in Aristotle in early modern times after having previously been rare. If the numbers of all these words are added up, a rather stable value between $1 \%$ ond $1.5 \%$ is reached. The core scientific and scholarly terms seem to remain of constant and high importance across more than two thousand years.

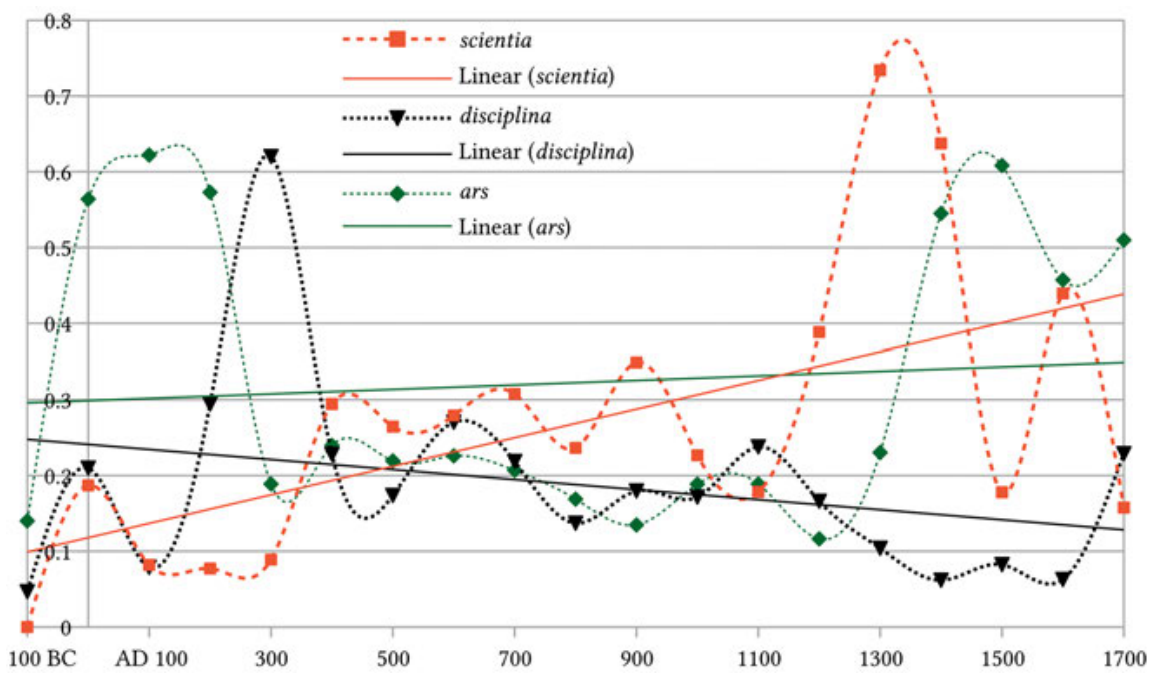

Fig. 3: The lemmata scientia, ars, disciplina in \%o for the 163 million words of all the texts in Corpus Corporum (as of November 2019), per century. The value at 200, for example, is the sum of all instances in authors who died (or, if unknown, floruerunt) between AD 101 and 200. Linear regression trend lines are added for the three words. Dotted lines are polynomial best-fits; they illustrate rather strong fluctuation likely caused by the heterogenic source texts.

In order to gain more precise values for the three most central lemmata for 'science' in Latin (scientia, ars, disciplina), occurrences per thousand words for all 
texts in Corpus Corporum are plotted diachronically in figure 3. As all meanings of the three words are counted in the plot, it may be better to refrain from drawing overly ambitious conclusions. Nonetheless, it would seem that the importance of the term scientia already overtakes that of disciplina in Late Antiquity, ${ }^{93}$ and that of ars (think of artes liberales) in the twelfth century, as the trend lines nicely hint.

The corpus of Croatian Latin used for early modern times in table 2 may have a humanist belles-lettres bias. In early modern times - during the Scientific Revolution - the word scientia hardly declined in popularity. Other data will be biased too; for instance, the numerous works by Thomas Aquinas are responsible for the huge peak of scientia in figure 3; indeed, the authors and texts were not selected according to any methodological principle. Nonetheless, it seems clear that scientia becomes the most frequent of these terms as time advances and that its frequency rose in Late Antiquity and again in scholasticism, and possibly again at the end of the Middle Ages. Indeed, its linear trend line ${ }^{94}$ in the illustration more than quadruples during the 1,800 years depicted, in contrast to the other two words, whose trend lines remain more or less constant or even fall.

\$11 In order to understand a semantic field fully, more than a look at near-synonyms is necessary. We now widen the scope and sketch a further circle of words involved in this semantic field. The relationship between the key terms will be studied further in chapter 5. Many of the terms that came to be connected more loosely to the semantic field of 'science' are defined by Aristotle in his book of de-

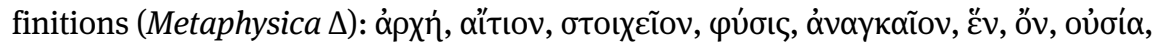

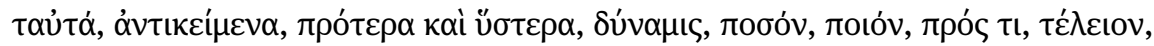

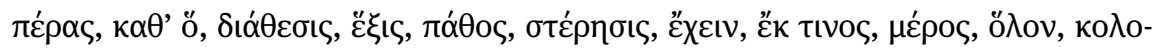

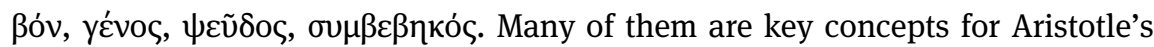
way of practising science and philosophy, and will remain very important for two millennia. Other important concepts could include $\theta \varepsilon \omega \rho i \alpha$ (contemplatio, speculatio) - opposed to $\pi \rho \tilde{\alpha} \xi ı \varsigma$ (praxis, actio), which roughly demarcates scientia from

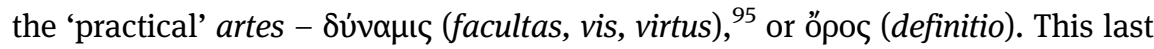
term was formalised and emphasised by Aristotle as fundamental for ensuring that people are speaking about the same thing. He claims that Socrates was the first to use strict definitions. ${ }^{96}$ Much further Greek scientific terminology was bor-

93 The peak exhibited by disciplina in the third century is mostly due to Tertullian.

94 Linear regression with ordinary least squares was used. Of course, the data does not have to be linear at all, but the line still illustrates the overall growth.

95 For Plato see Souilhé (1919).

96 Metaphysica M3, 1078b. 
rowed from legal terminology, which, just like science, had to use proof and logical argumentation.

- $\quad \alpha i \tau i \alpha / \alpha i ̈ t ı v,{ }^{97} \pi \rho o ́ \varphi \alpha \sigma ı \varsigma^{98}$ (causa), still also the legal 'cause' today. It may be noted that in Antiquity the concepts 'cause' and 'reason' are not separated.

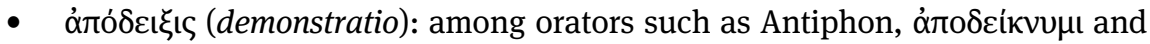
$\varepsilon \dot{\pi} \delta \varepsilon \dot{k} \kappa v v \mu$ are used to show that a case is sufficiently established (Lloyd

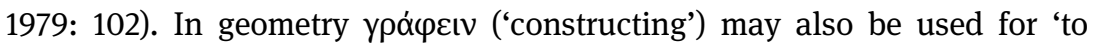
prove' (Lloyd 1979: 106); in jurisprudence it means 'to indict'.

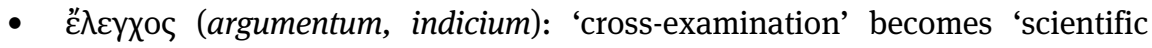
proof'.

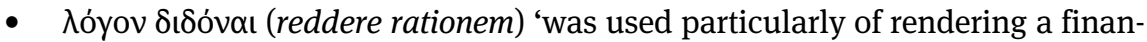
cial account' (Lloyd 1979: 253), until Plato, for whom it means 'to give a (philosophical, scientific) account of a phenomenon'. 99

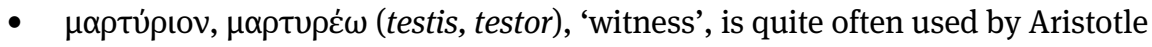

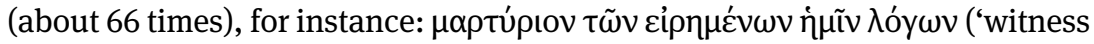
of what we have said'; De caelo II.9, 291a7).

- vó $\quad$ os (lex), which will become 'law of nature' among the Stoics, who coin the

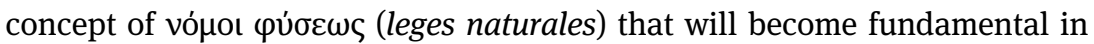
early modern times. Its first surviving occurrences are in Philon of Alexan-

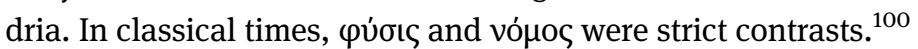

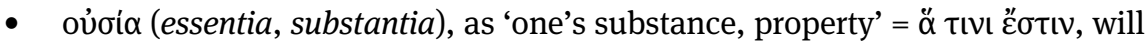
be the word of choice for Plato and Aristotle for 'stable being', which in some

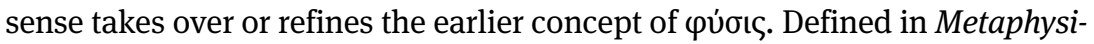
ca $\Delta 8,1017 \mathrm{~b}$.

- $\quad \pi \rho \tilde{\alpha} y \mu \alpha$ (res) 'business, esp. law-business', another term that will remain important in various circumstances, eventually leading to realitas (a common word in Neo-Latin philosophy) ${ }^{101}$ and our 'reality'.

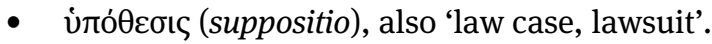

97 Lloyd (1987: 290), offers a list of its use in Hippocratic writers, where the meaning 'blame' is often still present, too.

98 Used thus in the Hippocratic De morbo.

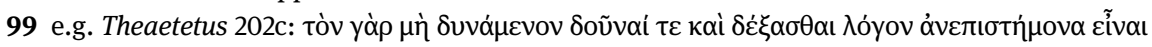

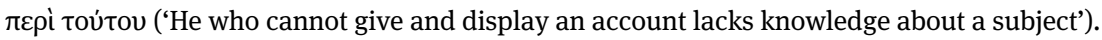

100 Kullmann (2010) shows that the concept of law of nature exists already in Antiquity, especially in Stoicism. Augustine, De Genesi ad litteram libri duodecim 9.\$17, ed. Zycha, p. 291, says: Omnis iste naturae usitatissimus cursus habet quasdam naturales leges suas ('This entire familiar course of nature follows certain natural laws of its own').

101 Although already common in Duns Scotus, other authors who use it often are Francisco Suárez, Spinoza, and Descartes. 
Besides this strikingly legal terminology, which may have found its way into the philosophy of Socrates' pupils through sophists, who were very much interested in legal matters, there is the idea of nature as a craftsman. ${ }^{102}$ Thus, terms such as $\varepsilon \dot{\mu}$ $\pi \varepsilon \iota$ í $^{\prime}$ (experientia) ${ }^{103}$ or peritia are often encountered in the ambit of 'science'. The craftsman god fashioning the material world in Plato's Timaeus is a famous case. Some other Greek words that have been crucial in philosophy and science stem from or received a decisive twist in their meaning from the ancient 'sages'. Exam-

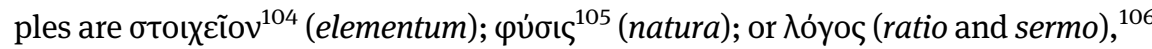
which we encountered above (introduction §2) as a hardly translatable Greek term. In Thaetetus, Plato tries to find the precise meaning of $\lambda$ óyos (from 206c onward) ${ }^{107}$ and finds three meanings: 'word', a more mathematical one close to 'ratio', and 'distinguishing mark or token' of something (thus coming close to 'definition'). This last meaning of a thing's $\lambda$ óyos as its definiens is then chosen as the appropriate one for philosophy; it enables a 'scientific' grasping of something (208e):

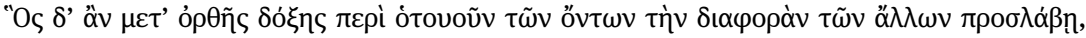

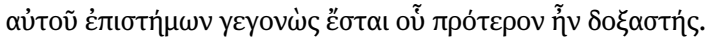

102 On which see Solmsen (1963).

103 Experientia and experimentum are usually synonyms and mean 'test' or 'experience'. The meaning '(scientific) experiment' is late, as is the idea of an artificial and alterable, premeditated set-up to study a certain phenomenon. Galileo and Lavoisier are often mentioned as pioneers of the latter.

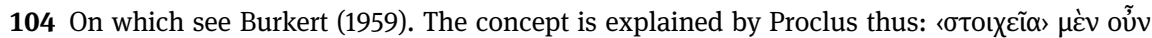

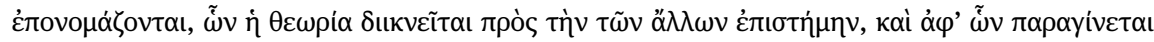

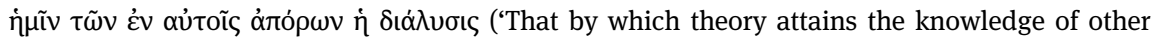
things is called "elements"; from these the solution of the difficulties in those other things reaches us'; In primum Euclidis elementorum librum commentarii, ed. Friedlein, p. 72).

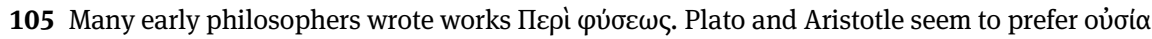

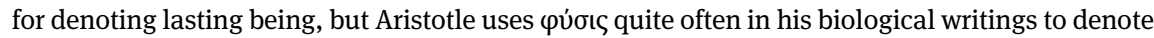
a quasi-personalised source of teleology. On this term, see Holwerda, Commentatio.

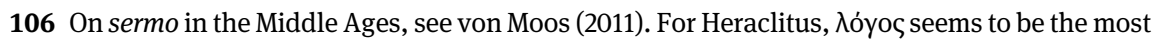
important principle of the universe; its famous career is further illustrated by the beginning of John's Gospel and the later Christian use of $\Lambda$ óyos for the second person of the Trinity.

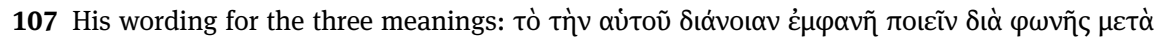

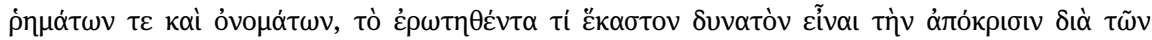

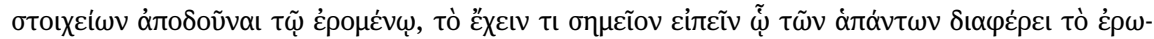

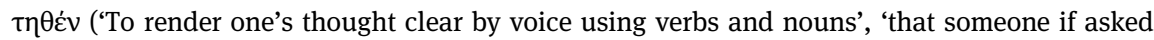
about it must be able in reply to provide his questioner with an account in terms of its elements', 'to be able to tell some characteristic by which the object in question differs from everything else'; 206d, 206e, 208c). 
'He who has adduced by correct opinion the difference from other things about something he will have become knowledgeable ( $\dot{\varepsilon} \pi \sigma \tau \eta \dot{\mu} \mu \omega v)$ about what beforehand he was only opinionated about.'

\$12 It has become clear that much of this semantic field goes back to Plato and Aristotle and thus to classical Attic, with some terms having survived from Ionian speculation. The chronology of these processes will be studied in more detail below (chap. 7). The Latin terminology is mostly an interpretatio romana of the Greek semantic web. None of the Latin terms considered here lacks a clear Greek predecessor, although some (especially disciplina and ratio) have taken on a different Roman set of meanings: thus, ratio could not cover the entire ground $\lambda$ óyo does, and disciplina seems to have moved from its natural 'epicentre' of $\mu \alpha \dot{\theta} \theta \eta \mu \alpha$ to

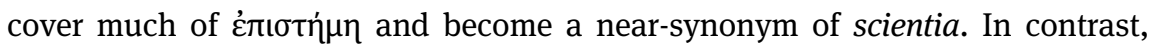
some Greek terms were just loaned in Latin (historia, philosophia, methodus).

If after these considerations we pause and ask ourselves to what degree premodern times had a concept of 'science' similar to the one we have today, it becomes evident that although there was not one clear-cut term for it before the twelfth century, several Greek and Latin terms seem to point toward such a con-

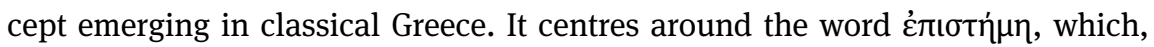
however, like Latin scientia, continues to be used in a more general sense for any kind of 'knowledge'. In Antiquity and the Middle Ages, the terms Tغ́ $\chi v \eta$ (ars) and the Latin disciplina are also often used where we would expect 'science'. Only from the later Middle Ages, in the wake of access to more Aristotelian works in the Latin West, does scientia become the standard word for what is now clearly perceived as a special human activity, 'science', in need of a unique name. Despite this slow development, it has hopefully become clear that an organic unity of something recognisably similar to our 'science' can be traced in authors through this time span - Aristotle, Archimedes, Ptolemy, or Boethius, say. From the twelfth century onward, the case is beyond doubt. Part 2 will depict this development in more detail, including key quotations from the sources.

These preliminary semantic studies will help us define a set of characteristics for scientific studies that can be applied to the entire, long, time span under scrutiny (chap. 4); after this we shall return to the question of how the key terms discussed in this chapter relate to one another over time (chap. 5). 